\title{
How Terrorist Groups End: Studies of the Twentieth Century
}

\author{
By Christopher C. Harmon
}

Terrorism studies are too young to have their Arnold Toynbee. Scholar Walter Laqueur has perhaps come the closest. At this writing in mid-2009, there remains a need for broad and searching inquiries into why and how terror groups have declined or ended. The project requires detailed knowledge of scores of important groups, extant and extinct, worldwide. The project also demands originality, so for this chapter we have set aside the useful frame I developed in 2003 and worked publicly for five years. ${ }^{1}$ It is hoped that a fresh sowing in this vital field will help with the understanding of what we have seen in the twentieth century.

\section{The Early Twentieth Century}

From the nineteenth century, the twentieth inherited several forms of violence that would dramatically influence politics and terrorism. Three that were important, and very different, were labor militance, anarchism, and communism. These three schools of thought and action profited from liberalism and rationalism; they were internationalist, and by degrees each supported workers and the poor. The most honest and credible of the three was the first, Labor - the drive for the rights and wages of blue-collar working men, women, and children, but a drive that sometimes assumed violent means and took innocent lives.

1 Scholars must recognize certain intellectual debts, and good scholars enjoy doing so. My debts are happily paid in this and earlier places, especially to Martha Crenshaw. One begins with her essay "How Terrorism Declines," in Terrorism and Political Violence, Vol. 3, No. 1 (Spring 1991), 69-87, and its admirable chart. There was a distinctive direction to my body of earlier work on this subject (e.g., many public presentations in 2004, a speech on Capitol Hill, a webcast from the Woodrow Wilson Center in Washington, DC, on 20 March 2006, a book chapter with Cambridge University Press early that year, etc.). It was to retrace researches I'd made over a previous quarter-century, present a half-dozen leading reasons for terrorist group decline, and then detail examples within each rubric. The present essay's approach is new, guided more by chronology, and my analysis profits from continued study of the individual named terror groups. Endnotes for Ch. 7 of my book Terrorism Today, 2nd ed. (London \& New York: Routledge, 2007) indicate other resources I found worthy. 
THE QuARTERLY Journal

\section{Labor Militance and Violence}

International labor organizations arose from, and sometimes parallel to, older and more local and national models. Their members were overwhelmingly partisans of a fair wage, decent hours, and protection of children from brutal factory work or endless hours. Novelist John Steinbeck wrote sympathetically of the California farmworker unionizers who organized strikes or demands for better wages or improvement in camp conditions. But other activists stepped well over the lines of public pressure and civil opposition. The organization called Workers of the World, or "Wobblies," conducted strikes but also sabotage ${ }^{2}$ of property. Individual militants or groups of organized labor undertook the beating or killing of bosses, night watchmen, or "big capitalists." Cities as different as Seattle and New York witnessed laborites' assaults on the innocent. A few representatives for a union of iron workers and bridge builders coordinated an ugly bombing campaign in the United States in the fall of 1910 that took two dozen lives, injured others, and massively damaged property. ${ }^{3}$ The labor movements also produced theorists and public advocates (e.g., in France, Georges Sorel). They advocated violence - usually accompanied by other political aims and strategies that might appeal to the sympathetic mind and to the average citizen.

American labor violence succeeded, in its way, according to the best US historian of terrorist movements, Walter Laqueur. "The daily wage of American iron workers (AFL) went up from $\$ 2.00$ to $\$ 4.30$ (for shorter hours) between 1905 and 1910 as the result of the bombing of some one hundred buildings and bridges. ${ }^{4} \mathrm{He}$ adds that Spanish workers, using similar methods, improved their wages during the First World War. ${ }^{5}$ To violence, and that powerful display the strike, labor militants added mediation, sweet reason, unions, and other factors. These combinations improved labor conditions and pay. There was steady growth and legitimization of unions. As this occurred over decades, sporadic labor violence did not end, but it came to be seen in the American public mind as separate from political notions such as anarcho-syndicalism

2 The Dutchman's wooden shoe, or "sabot," made a sort of weapon if a laborer wanted to jam it into machinery at the workplace. "Sabotage" normally falls short of "terrorism," and its perpetrators sometimes intend avoiding human casualties, as do many practicing "ecotage" on behalf of the wild world. One nineteenth-century American form of sabotage by laborers/ militants is the activity of the "Molly McGuires," who damaged their own coal mines in eastern Pennsylvania from about 1862 - until ten were hanged in 1877.

3 Joseph T. McCann, Terrorism on American Soil: A Concise History of Plots and Perpetrators from the Famous to the Forgotten (Boulder, CO: Sentient Publications, 2006), 33 40.

4 Labor histories by L. Adamic and G. W. Meaker are cited by Walter Laqueur, The Age of Terrorism 2nd ed. (Boston: Little, Brown \& Co., 1987), 75.

5 Ibid. 
or communism. All these are among the reasons labor violence overturned so few economies and political orders of the early twentieth century.

\section{Anarchism}

Although it often lauded the poor man or hated the rich man, anarchism was never essentially and directly about conditions in the workplace, or the economy. It was obsessed with the state, more than the state of the working man. Anarchism despises political authority as inherently repressive and antihuman; it thus drives to bring down government, all government. The Russian Peter Kropotkin, born a prince before becoming an anarchist, drew a line between his confreres and Communists on the issue of the state: "To this question the anarchists alone give the proper answer: 'No Government!' All the others say 'A Revolutionary Government." ${ }^{\prime \prime}$ In the last third of the nineteenth century, and during the early twentieth, anarchism was distinctively international for reasons that were philosophical, first, and operational, second. The important activists often traveled (or fled) abroad, knew one another or corresponded, employed each other at publishing houses and journals, read each other's broadsides with their internationalist rhetoric, and saluted the others' violent actions as laudable "propaganda of the deed." They helped foreign fugitives find haven from the law, find work, or find comradeship. ${ }^{7}$

Violence joined up with philosophical anarchism in Russia at the end of the 1870s. Soon, given the devolution implicit in arguments for both violence and anarchism,

6 From the Revolutionary Pamphlets, quoted by Mikkel Thorup, "The Anarchist and the Partisan: Two Types of Terror in the History of Irregular Warfare," Terrorism and Political Violence, Vol. 20, No. 3 (July 2008), 338. Peter Kropotkin's Memoirs of a Revolutionist are valuable for many reasons, including references to the role of police action (and capital punishment) in Russian suppression of its anarchists. The book was published in English in both the United Kingdom and the United States in 1899, appearing later in Russian.

7 There are occasional scholars' assertions that pre-WWI anarchists were not networked internationally. Perhaps not; who can argue that anarchists are well organized! Yet, there are levels of collusion and coordination in some sectors - just as anarchists today organize on the World Wide Web. The scattered indicators include the face that the number of nineteenth- to early twentieth-century Italian anarchists operating across borders was very high. Entities such as study groups and newspapers fostered networks. Usually, perpetrators were students of the others' actions: even one of the most autonomous of all the anarchist murderers - a US-born, ethnic-Czech named Leon Czolgosz, who shot President William McKinley - carried in his wallet a folded news clipping about a recent anarchist murder elsewhere, and was careful to purchase the same make of revolver, the .32 caliber Iver Johnson, that an anarchist had used to shoot King Humbert I of Italy. McCann, Terrorism on American Soil, 27, ff. 
theorists such as Kropotkin and Mikhail Bakunin ${ }^{8}$ praised all actions that destroyed, from petty crime to grave assault. ${ }^{9}$ The spiral downward led to adulation for "infernal machines" (usually dynamite bombs). The Russia of the late nineteenth century saw anarchism embedded with both low crime and flaming political idealism. The movement targeted senior defense, intelligence, and police officials, not just political governors. The revolutionary concepts were exported, and the colluders turned up to write, preach, and kill in the United States, Italy, Spain, Germany, and France. Anarchists hid out for periods in Switzerland, supporting themselves in journalism, printing, or other trades; they thus lived ironically-in a prosperous country amidst donors' money, chemicals for bomb-making, printing presses and newspapers, transportation, and the like, while working daily and nightly to destroy it all for a vision. International anarchists believed they could win. They could at least kill and they could reduce a city to general fear. Historian Barbara Tuchman depicts Paris at one time in the grip of "mad bombers"- streets deserted, shops shuttered, panic evident in the public. ${ }^{10}$

Why did this anarchist movement die? Indeed it did end: incidence of violence fell off dramatically, as in Italy and France after 1900. In the United States, the movement appeared to peak about 1908, and touched another summit in 1919. But one hears little of new lethal attacks after 1920 — the year of payroll robbery and murder in Massachusetts by Ferdinando Nicola Sacco and Bartolomeo Vanzetti. It is also important to recognize that it was a movement—not a freakish wave of public interest, or a political party, or a disciplined formation of cells. Anarchism was international; it was networked (to use a modern term); ideas drove the actors; there were clandestine levels as well as public faces; some adherents were lethal and some were utterly fearless. For these reasons, the movement suggests parallels with the contemporary Salafist Islamic movement, best known for the much-narrower al Qaeda organization. And how it perished is thus doubly important.

8 The Kropotkin quotation from 1880 is again from Professor Thorup. Bakunin is quoted in 1869, in his Principles of Revolution, cited by W. Laqueur, 30.

9 Sometimes their exultations in the "liberating effects of violence" foreshadow Frantz Fanon, author of The Wretched of the Earth - but he would write and work as an insurgent for Algerian self-determination, not as an anarchist. All of Fanon's books help us understand modern terrorism, yet many post-September 11 academics barely know of him.

10 Barbara Tuchman, The Proud Tower: A Portrait of the World Before the War, 1890-1914 (New York: Scribner/Macmillan, 1966). 
Until recently, little was asked about the mystery of, and few good answers delineated reasons for, the death of violent anarchism. ${ }^{11}$ New studies of the terrorists by Richard Bach Jensen, as well as Ersel Aydinli, demonstrate how state intelligence units, policing agencies, and other governmental offices and legislatures had profoundly important roles. Italy and Russia took leads in multistate action to coordinate border control and extradition. American cooperation with foreign states came slowly, too slowly, but did come. Creating the Federal Bureau of Investigation at home helped: It meant that investigators of anarchists no longer had to borrow manpower from the minuscule Secret Service, and also that a national register could be kept to allow information exchange and coordination across hundreds of local, county, and state jurisdictional lines. Europeans adjusted internal laws, as in banning open anarchist meetings, and enhancing court powers over conspiracy (i.e., revolutionary activities short of attacks). Russian services performed ruthlessly, locking up suspects and executing anarchists. Russian police, much provoked, were very aggressive; after October 1917 their successors set new standards in the use of force. In short, governments worldwide stiffly countered the anarchists. ${ }^{12}$ Thus, The Economist may well be wrong in its conclusion to a fascinating four-page review of the century-old phenomenon (published in 2005): "So why did their wave of terror pass? Not, it seems, because of the measures taken to deter them."13 For The Economist, the arrival of The Great War in 1914, and the Russian Revolution soon thereafter, made the difference. And surely these were important, new, and perhaps overwhelming, robbing

11 In my work of 2004-2007 I argued that not only terrorists - but even their doctrines might be defeated in some times and places. A majority of communist terrorist groups failed. Anarchist violence alienated most workers, police, and other government forces turned against the movement, jailing the leaders, etc.; e.g., "How Al Qaeda May End," Backgrounder \#1760, The Heritage Foundation (19 May 2004).

12 Terrorism and Political Violence is the journal leading this conversation on anarchism. Richard Bach Jensen made a fine and original presentation on "The United States, International Policing and the War against Anarchist Terrorism, 1900-1914," in Vol. 13, No. 1 (Spring, 2001), 15-46. The journal printed a useful and related article by Mikkel Thorup seven years later, and then a further Jensen essay in 2009, "The International Campaign Against Anarchist Terrorism, 1880-1930's," Vol. 21, Issue 1 (January 2009), 89-109. See as well Ersel Aydinli, Chair of the International Relations Department at Bilkent University, Ankara, "Before Jihadists there were Anarchists: A Failed Case of Transnational Violence," Studies in Conflict \& Terrorism, Vol. 31, No. 10 (October 2008), 903-923.

13 "For Jihadist, Read Anarchist: repression did little to stop anarchist violence. But eventually the world moved on and the movement withered," The Economist, 20 August 2005, 17-20. The authors' inquiry led them to such causal factors as the coming of World War I and the Russian Revolution - which surely played roles in the expiry of this movement. But they neglected US Supreme Court decisions on labor issues and other factors a magazine had no particular duty to cover. 
anarchists of public interest. But two titanic events do not displace all quieter workings of history: being much provoked, states focused, and then responded, and with good effect. ${ }^{14}$

\section{Communism}

The October Revolution brings our account to the third and final school of thought bridging the nineteenth and twentieth centuries and relevant to terrorism. After labor militance and anarchism, there came communism. It had been visible, by degrees, in Narodnaya Volya (People's Will), a Russian terrorist group of the late 1870s. Its Central Committee believed that if a dozen pillars of government and security would collapse, the whole of government would tumble as the masses rose up. But the group's ideology was hazy- as much anarchist or pro-farmer as communist. Purer political revolutionary forms, such as those filled by Mensheviks, Bolsheviks, and Social Revolutionaries, attended to how government would be reformed and would work, not only to how it initially would be destroyed. They dreamed of new gleaming towers but also had the maturity to plan for them. Communists often debated the issue of terrorism, and later students of such debates have an inappropriate tendency to fix on deprecatory remarks of famous Bolsheviks about the foolishness of individual terrorism - as Vladimir Lenin suggested in titling a booklet Left-Wing Communism: An Infantile Disorder. ${ }^{15}$

Such vanguardsmen of the era as Trotsky and Lenin did make the argument, in the course of a career in politics, that terrorism could be stupid or self-defeating. But these same communists used terror, and argued for terror, when it served their revolutionary purposes. What they ridiculed was not "the deliberate and systematic murder, maiming, and menacing of the innocent to inspire fear for a political end." ${ }^{16}$ What they opposed was

14 Numerous anarchists' cases could be cited. Consider Sergei Gennadevich Nechaev, the young Russian author of the 1869 Revolutionary Catechism. He committed a murder in Moscow and fled to Geneva, but the Swiss extradited him back, and he died in Russian prison. Significant here are both the Swiss act of extradition and the Russian willingness to punish with a lengthy jail term. James Joll, The Anarchists (New York: The Universal Library, 1966), 93-96.

15 During the second term of the Reagan-Bush presidency, in the late 1980s, a US historian of Russia and the USSR took me aside after a speech to advise that, despite what many might think of communists, Lenin opposed terrorism. My own readings to that time, in primary sources and in Chapter 2 of Roberta Goren's The Soviet Union and Terrorism (London: George Allen \& Unwin, 1984) had indicated that his view was predominant but errant. I thought of the irony: "simple" politicians such as Ronald Reagan were more correct than "sophisticated" academics on the question of Bolshevik support for terrorism.

16 This most useful definition of terrorism was proposed and used in publications by The Jonathan Institute, a think-tank, at the end of the 1970s. 
individual terrorism uncontrolled by their tight party. The Lenin who could mock bombthrowers as "infantile" penned a letter to the "Combatant Committee" of St. Petersburg in 1905 urging revolutionaries to robbery, arson, and other terroristic acts, insisting that they stop blathering about bombs and begin using them. ${ }^{17}$ Leon Trotsky, commander of the Red Army, thrilled to the power of both communist dictatorship and terrorism against counterrevolutionaries, penning a book exalting both, three years after the revolution. When the Soviet secret service murdered Trotsky in exile, it served as one more demonstration of how, once in power, Bolshevik communists viewed terror as they had while rising to power: through the eyes of cold utilitarianism.

After 1945 a new chapter opened for communism-one of both remarkable state power and renewed interest in expanding the revolution abroad. Terrorism kept some of its roles. International terror had some links to communists, their international organizations, and certain of their capitals. ${ }^{18}$ Rulers of communist East Germany criticized terrorism during the high Cold War, but for years they funded Konkret, the radical newspaper in Berlin to which Ulrike Meinhof contributed, and both parties helped this relationship grow into provision of counsel and safe-haven to her Red Army Faction (RAF). ${ }^{19}$ Serious communists, like serious anarchists, long for the state

17 See also Lenin's pamphlet Where to Begin of 1901, which explains that, when local revolutionary organizations are weak, the "individual attack" can be highly useful.

18 This is clear - but it was much debated at the end of the 1970s and the early 1980s. See for example the documents in Ra'anan, Uri, Robert Pfaltzgraff Jr., Richard H. Shultz, Ernst Halperin, and Igor Lukes, Hydra of Carnage: The International Linkages of Terrorism and Other Low-Intensity Operations: The Witnesses Speak (Lexington, MA: Lexington Books, 1986). There is considerable evidence in the books and other works of Ray Cline, Paul Henze, Michael Radu, and others.

19 East German support to the RAF was detailed early on by Jillian Becker, Hitler's Children: The Story of the Baader-Meinhof Gang, 2nd ed. (St. Albans \& London: Granada Publishing Ltd., 1978), Chapter 9. Her brilliant volume never attained the full attention it deserved, and now seems almost forgotten, even during a revived interest in the RAF that peaked in 2008 with the new movie "The Baader Meinhof Complex." Years ago, a popular German newspaper also reported on East Berlin's subsidization of Konkret. And American journalist Claire Sterling wrote a book about these and similar linkages (see below, n. 48). She was often derided for unthinking anti-Communism. But as the wall came down, a wave of records followed to show how the Bloc had supported terrorists operating in Western Europe and other regions. These confirmations and revelations were widely reported, as in the New York Times, over a number of years. Thanks to the George C. Marshall Center and its translators, I have been able to obtain and study a 3 May 1979 example prepared in Berlin, Stasi document MfS - HA XX11, Nr. 18613, 16 pp. long in German, "INFORMATION on Activities by Representatives of the Palestinian Liberation Movement, in Conjunction with International Terrorists, to Involve the GDR in the Preparation of Acts of Violence in Western European Countries." That document discusses the free movement in Eastern Europe of Palestinians, their allies such as Carlos, and the Germans of RAF and 2nd of June Movement, and the Stasi's "goodwill and loyalty" shown to them. 
to disappear; many in both schools are certain that much violence is required to bring this about. Study of only tactics may confuse; thus, some observers imagine that the German RAF was more anarchist than communist - a myth easily dispelled by reading their communiqués. While the two movements differ on what happens after the revolution, the communist knows that anarchism, revolutionary spirit, and terrorism all have their virtues; their utility will depend upon timing and circumstance, and upon who becomes damaged and who benefits. And so the German Democratic Republic was just one of many communist bloc states supporting terrorist cells abroad.

The twentieth century lived with and endured communism. Witnesses, participants, and victims saw its stages of nascence, its rise to power, its dangerous status as deliberator over half the world during the high Cold War, and its sudden decline in authority by 1990. During eight decades in which its adherents governed important states, terrorism, whether guided by, or aided by, communists, took unnumbered lives. A minority of these perished in classic, archetypal international terrorist attacks by communist groups with communist state sponsors. Many died in other kinds of violence when communists were seeking power. Many more died in communist states after power was successfully taken. The human damage has been chronicled (e.g., by a man such as Alexander Solzhenitsyn, or in long lines of zeros, as added by the team of French academics who compiled the The Black Book of Communism, 1997).$^{20}$ In the end, among the many and diverse classes of victims were individual industrialists and arms-makers and top politicians in Europe; tens of thousands of village leaders hunted down over time in Indochina from 1940 to 1975; peasants in Asia caught up within insurgencies; and certain whole villages in Colombia and Peru, which dared to resist the revolutionaries via poorly armed militias. Communist terror came to dozens of other places and in myriad conditions. In four or five years, gunmen with a revolutionary dream could turn a pristine, admired city of one million such as Montevideo, Uruguay, into a war zone of urban strikes and daily gun battles, as the Tupamaros did by 1970 .

No scholar has thoroughly studied and described the many ways that late-twentieth-century communist terror groups came to their ends, but it is errant to assume that they fell when the Soviet bloc did, in 1989 and 1990. First, many communist militants did not fall; they fought on, as Revolutionary Organization 17 November did in Greece. It was never touched by the Greek state and was indeed only broken

20 Harvard University Press; ed. Stephane Courtois. 
by a bomber's accident in 2002, allowing a wave of arrests. ${ }^{21}$ Second, other communist state-supported groups fought on and live even now; for example, the National Liberation Army (ELN) in Colombia long ago became self-supporting. Today has outlasted the Soviet bloc by two decades and keeps several thousand men and women in the field. Third, certain communist groups did not fall with the Kremlin but perished well before. This was true of the Belgian Communist Combatant Cells. Most Italian leftist terror groups disappeared before 1990. Law enforcement was the usual primary reason.

The German Red Army Faction (RAF), or Baader-Meinhof group, did not quickly disappear, but it too failed. RAF did not announce its dissolution and failure in a communiqué until April 1992, proximate to the world-shaking fall of the wall. But the group's real end was signaled as early as 18 October 1977 . On that day, four of the imprisoned RAF leaders - including lovers Andreas Baader and Gudrun Ensslinattempted suicide (three of four succeeded). The Lufthansa jet their comrades had hijacked to bargain for the freedom of the prisoners in Stammheim jail was recaptured by elite West German border guards (GSG-9), who shot all the hijackers in the action. With only a handful of quarrelsome confreres still operating inside the Federal Republic, the RAF experienced despair. The wiser of them understood that after eight years of terrorism they had made astonishingly few allies among sixty million normal Germans, people whose lives were democratic, whose self-governance centered in Bonn and more local places, and whose economy was a shining success. The RAF thus tottered along after 1990 and 1992, but few new members joined, and nearly all who did were uncovered by diligent police work. ${ }^{22}$ The Federal Republic

21 There are two good English-language accounts (known to me) of the precipitous fall of Nov. 17th. A gifted student at the Institute of World Politics in Washington, DC, aviation security expert Mr. Paris Michaels, wrote an unpublished 2003 paper for our course. George Kassimeris of the Univ. of Wolverhampton, England, published a detailed article, "Last Act in a Violent Drama? The Trial of Greece's Revolutionary Organization 17 November," in Terrorism and Political Violence, Vol. 18, No. 1 (March 2006), 137-157. The group's head of operations is quoted saying the group was finished as a terrorist organization yet could return in some other form: "perhaps, in ten to fifteen years' time, a new generation of fighters for the people might re-launch the struggle." (153). It may be relevant that several Greek cities faced protracted rioting in late 2008, following a police shooting, and that since 2003 a terrorist group called Revolutionary Struggle has emerged.

22 I have often spoken in past lectures of the roles of Horst Herold and German police in the attrition of RAF cadre. Introducing "computer profiling" and diligence with detail allowed federal authorities to find, one by one, the RAF militants. As there were never more than a few dozen weapons-carrying members, arrests reduced the group to nothing. In recent years, nearly all members have been released from jail. The unrepentant Hans Christian Klar, guilty of 20 murders or attempted murders, won early release in late 2008, prompting debate in Germany and this comment by Bavarian justice minister Joachim Hermann: "Klar deserves no sympathy as long as he continues to show none for his victims." Christian Science Monitor, 22 Dec. 2008, and BBC News, 19 December 2008. 
was no oppressor, and there were no profound "roots" to terrorism requiring excision, but only a shallow and shoddy malaise in some elites. In a tribute to how democracy may calmly mobilize, active security forces, operating carefully under the law with enhanced intelligence, they eventually reduced all remnants of the minuscule Red Army Faction.

Similar diligence by security forces and governments in France, Belgium and Italy undercut and effaced those countries" "Fighting Communist Organizations."23 Regional cooperation by authorities developed as well. ${ }^{24}$ Proper extraditions of fugitives thus gradually trumped older presumptions of the "asylum rights" of political terrorists, making foreign refuges challenging to find. When EUROPOL was born, it confirmed the best tendencies in European politics as well as developments since the Maastricht accords reduced national borders in 1992. If this maturing organization comes to move firmly against transnational terrorists - in the way that INTERPOL has done recently under Secretary General Ronald Noble ${ }^{25}$ - the healthy effects of international action will be enjoyed more by European society.

Today communism is exhausted in most locales. But it has not died. "Naxalites" dominate great parts of central-eastern India. Counterparts of a Maoist calling have reached a peak of power in Nepal, entered parliament, and taken the Prime Ministry, shelving terrorist methods - at least in most places, at least for now. Their terrorism has been placed on "pause" while they share power. Colombia has badly damaged

23 This appellation, often self-applied by the terrorists, was taken up by two scholars as a subtitle for their fine book: Europe's Red Terrorists: The Fighting Communist Organizations, by Yonah Alexander and Dennis Pluchinsky (London: Frank Cass, 1992). They include several post-1990 RAF documents, such as the aforementioned confession of failure dated 15 April 1992. 1998 occasioned yet another confession of failure from an RAF hand, so that year, too, appears in print sometimes as "the end of the Baader-Meinhof organization."

24 One careful listing of relevant regional and subregional offices and organizations is by Florina Cristiana (Cris) Matei, "Combating Terrorism and Organized Crime: South Eastern Europe Collective Approaches," in Bilten Slovenske Vojske, the journal of the Slovenian Armed Forces (Sept. 2008), 37-58.

25 In its first decades, the Lyon-based INTERPOL explicitly kept its distance from terrorism cases because its new authority might not be helped by political quarrels. But now INTERPOL handles terrorism acts more and more as they do other crimes. Also, governments' use of the agency's capacious data bases has dramatically expanded, for terrorism cases as well as others. Mr. Noble was unanimously elected to a second term of office in 2005 and came to Garmisch to address our Program on Terrorism and Security Studies on 23 May 2008 . 
ELN and Revolutionary Armed Forces of Colombia (FARC) ${ }^{26}$ regions, but neither insurgency is at an end. Peru's Sendero Luminoso, or Shining Path, decapitated by 1992 arrests, is reportedly attempting a "comeback" after a decade and a half of impotence. But in Europe, the United States, and some other regions, factors including the collapse of the Soviet Union have persuaded most that communism has little future, and thus that its violent methods cannot be justified. Mainland China seems only to underscore the decline of communism's foreign meddling of militant sorts. In the 1960s and 1970s, Chinese advisors serviced at least a dozen militant groups in Asia and Africa, including the genocidal Khmer Rouge. ${ }^{27}$ Today, Beijing presides over new economic strength and military power, but this parallels a decline in ideological commitment. Beijing seeks allies and oil; few if any official Chinese actions include direct support to violent sub-state groups. This apparent absence of Beijing's state support for violent revolution has been one reason for notable declines, in some regions, of terrorism. In other areas - where indigenous Maoist revolutionaries might perform better if they could only have Beijing's aid-the lack of foreign state assistance is important.

\section{Racism and Nationalism After World War II}

Fierce nationalisms lay behind two global wars of the twentieth century and myriad attacks of smaller scale. The wars of nationalism include many long-simmering lowintensity conflicts featuring terrorism and insurgency in the post-World War II era.

26 Teaching case studies of counterinsurgency success long ago convinced me that defections are a superior metric for decline. When Colombia's Vice Minister of Defense Sergio Jaramillo wrote "Pourquot le Temps Joue Contre les FARC" for Le Figaro, 23 January 2008 , he reported that 1,454 FARC members had quit in 2007, the double of the previous year. As this occurred in the context of much-enhanced skills and professionalism by the Colombian armed forces, I took it to be highly significant. A few months later, the Ingrid Betancourt hostage party was rescued in a Colombian special forces operation - another case in which years of negotiations failed but surgical force worked brilliantly.

27 Maoist China aided armed groups in Burma, Indonesia, Laos, Malaya, the Philippines, Thailand, and Vietnam, according to Quansheng Zhao, Interpreting Chinese Foreign Policy: The Micro-Macro Linkage Approach (Oxford: Oxford University Press, 1996), 55-56; available at http://books.google.de/books?id=tKmnESFGY8MC\&pg=PA48\&lpg=PA48\& $\mathrm{dq}=\mathrm{cHINESE}+$ support+to+revolutionaries\&source=bl\&ots=KmXYGUlmk2\&sig=brvv nnvcMlzOlhRI6ZjqoupAg8g\&hl=de\&ei=t0HYSuL4GoOJsAaXwdTyBg\&sa=X\&oi=boo $\mathrm{k} \_$result\&ct $=$result\&resnum $=3 \& \mathrm{ved}=0 \mathrm{CBQQ6AEwAjge} \# \mathrm{v}=$ onepage $\& \mathrm{q}=\mathrm{cHINESE} \% 20$ support $\% 20$ to $\% 20$ revolutionaries $\& \mathrm{f}=$ false. Aid may or may not include shipping arms. For example, I cannot document arms shipments by Beijing to the Filipino Huk communists or the New People's Army of a later generation. 
The Allies' crushing of fascism — a doctrine built upon racial and national exclusivity and superiority - could not prevent the rise of later racist or hypernationalist figures and movements. So while organized neo-fascist parties and movements of post-1945 years have often been small, they have had support of malcontents, reactionaries, and others.

A riveting example of "terrorist as political reactionary" was the Secret Army Organization (OAS), a last-ditch attempt by French and other Europeans to defend status quo European power in Algeria in the face of success by the indigenous National Liberation Front (FLN). Men of the OAS imagined themselves to be counter-terrorists, protectors of many decades of French improvements in the Maghreb. In fact they swiftly descended into nihilism. Their quick end in failure has obscured some of their very real strengths, however. OAS was formed by savvy leaders, enjoyed considerable financing, conducted hundreds of plastique bombings and assassinations, and had international sanctuaries (especially in Spain). OAS was also defending the status quo-which is normally easier than overthrowing it. But it was defeated in less than two years by a combination of Charles de Gaulle's government efforts and a near-absence of public support for the OAS except in limited and white circles in Algeria. Political forces labeled them as "neo-Nazis" and "assassins." At the operational level, in France as well as North Africa, police and government outsmarted the rightists: "It has been estimated that ten determined men fought and won the battle against the OAS in France. What they brought to the struggle was intelligence, political acumen, level-headedness, and personal toughness," according to Paul Henissart's history Wolves in the City. IBM computers were exploited, as well as networks of human sources. "In addition to using police tipsters, double-agents, and anti-OAS groups, [police] received information from thousands of private citizens loyal to the government." ${ }^{28}$ The Secret Army Organization was born in December 1960; it died in July 1962 when all but .02 percent of voting Algerians said "Oui" to independence.

It is not surprising that the OAS had found supporters among rightist European farmers and businessmen worried over loss of economic status in a prospective FLNrun Algeria. Similarly, many extremist and reactionary groups of the twentieth century have seen their ranks swell with economic crisis. The history of this pattern in Italy and Germany in the 1920s and 1930s is clear, and the rise of fascist street gangs of those days was clearly "terrorism." Waves of immigration into Europe and the fall of the Berlin Wall have had their own roles in spawning violent new racist or nationalist organizations. Today, smart analysts think about how the early twenty-first-century economic recession is affecting prospects of rightist and other terrorists. Economics

28 Paul Henissart, Wolves in the City: The Death of French Algeria (London: Rupert Hart Davis, 1971), 300-301. 
is merely one driver of politics. Many times, social trends or legislative changes have added to economic worries, and thus added volume to the calls to action. One further and recent example in US history is when the 1983 "Brady Bill" making guns harder to acquire had this effect on some right-wing Americans already angered by general recession and an acute farm crisis.

\section{Ghosts in the American Experience}

Both immigration and economic trouble have been connected in the United States to the long run and continuing life of the Ku Klux Klan (KKK). This organization was founded in the mid-nineteenth century, prospered, and moved readily into the twentieth. The KKK was in Canada, as well as many US states, where membership peaked from 1915 to 1925 . The first of those years marks the opening of the D.W. Griffith film Birth of a Nation-initially released as The Clansman, a powerful film seeming to idealize white supremacy and anti-black violence. The second date, a decade later, was that of a powerful political display: in Washington, DC, an estimated 40,000 Klansmen marched. Nor would the KKK disappear after the Second World War. Some American racists doubtless joined such groups as the KKK precisely in personal reaction against post-1945 liberalism, tolerance, and internationalism. US civil rights improvements and new laws could infuriate the serious kind of racist who joined the Klan; that paradox is instructive as to the nature of terrorism.

Mike German, a young FBI agent, penetrated several KKK and neo-fascist terror groups in the United States. He offers valuable research into how the Klan was forced into decline- though not defeated-beginning in the late 1920s. The complex of reasons includes (1) political infighting, which fractured the organization and has continued to do so even today; (2) scandals - as when violent episodes shocked the public, or an individual Klansman's actions tarnished the image of "protector of southern values"; (3) a change in American values, whereby the public's tolerance for racism declined, and many were moved by the exposure of fascism's atrocities and death camps overseas in the early 1940s; (4) federal government actions, especially a 1946 tax decision that damaged Klan business enterprises and the 1954 Brown vs. Board of Education Supreme Court decision on education that ended school segregation forever; and (5) the Klan murders of three civil rights workers in Mississippi in 1964, which horrified the US public. The cumulative effect was to thoroughly discredit an organization that since the 1880 s had often lynched and terrorized with impunity. ${ }^{29}$

29 Mike German, Thinking Like a Terrorist: Insights of a Former FBI Undercover Agent (Washington, DC: Potomac Books, 2007), 139-146. Now with the American Civil Liberties Union, Mr. German addressed our colloquium at Marine Corps University of April 2007 on "Terrorist Group Vulnerabilities." 
During the last half-century, the KKK has not possessed half the powers it once had in America. Together these are a veritable roster of terrorist group vulnerabilities - and they should suggest all kinds of possibilities to clever counterterrorism specialists.

Unfortunately, racism and terrorism from the extreme right in America have never been limited to the KKK network. There is a lengthy and distressing chronicle of maiming, menacing, and occasionally even murder of the innocent by other US groups preaching narrow or eccentric forms of white power religion and politics. Tiny political minorities, and even "lone wolf" actors, militants-usually maletend to imagine themselves to be heroic defenders of the racial majority in the fifty states. Consider only the last generation, and only lethal actions, often against black or Jewish victims. Among the earliest of these murderers was Gordon Kahl of Posse Comitatus in February 1983, in North Dakota. Richard Wayne Snell, of the Covenant, Sword, and Arm of the Lord (CSA), killed in Arkansas in 1983 and in June of 1984. ${ }^{30}$ Members of The Order, a white supremacist group, killed a man in June 1984 in Colorado. Neo-Nazi David Tate of The Order killed in April 1985. ${ }^{31}$ In Oregon, White Aryan Resistance-inspired skinheads of East Side White Pride beat a man to death in November 1988. A gap in lethal incidents followed, yet the far right returned: Timothy McVeigh, racist and anti-federalist, bombed and killed scores in April 1995 in Oklahoma. Militants hoping to found an Aryan Peoples Republic killed in Arkansas in 1997. A free member of the prison gang Confederate Knights of America, John William King, murdered in Texas in June 1998. Ben N. Smith of the World Church of the Creator killed twice in July 1999, in Illinois and Indiana. Buford O'Neil Furrow committed an August 1999 murder in California. In a testament to the significance of ideas_-not just personalities_-in terrorism, at least five of these latter acts are linked to the ugly racist novel, The Turner Diaries. ${ }^{32}$

30 Although this shooting (of a black state trooper) is missing in one comprehensive FBI booklet, the 30 June 1984 act is related in other sources, including Louis R. Mizell, Jr., Target USA:The Inside Story of the New Terrorist War (New York: John Wiley \& Sons, 1998), 186-187. The perpetrator was scheduled to be executed on 19 April 1995, which apparently helped settle Timothy McVeigh on this date for bombing the federal building in Oklahoma City.

31 Mark S. Hamm, Terrorism as Crime: From Oklahoma City to Al Qaeda and Beyond (New York: New York University Press, 2007), 109-110.

32 The Turner Diaries, a 1978 novel by William L. Pierce (writing under the pseudonym Andrew MacDonald), is linked to at least five killings or nonlethal terrorist incidents of 1995 2006; see the 2nd edition of my book Terrorism Today (New York and London: Routledge, 2007), 18-19. Other incidents in the present text are documented by the Dept. of Justice/ FBI publication Terrorism in the United States: 1999: 30 years of Terrorism, A Special Retrospective Edition (n.d. [Oct. 2001]), by Southern Poverty Law Center publications, and by media reports. 
What social and political forces contain and resist this modern-day terrorism from the racist right? One is federal leadership from Washington, be it in federal statutes or action against entrenched resistance in some states and localities. ${ }^{33}$ We return to the KKK: after the Civil War of the mid-nineteenth century, federal intervention had controlled or suppressed many indigenous patterns of racist behavior. This activism by Washington (including locking up thousands of Klansmen) was abandoned after 1882, with deleterious effects; when resumed after World War II, it proved again to be a vital element in the desegregation of the 1950s, and in the successful prosecution of terrorists in courts. Successive US presidents, the Justice Department, and other organs of federal power used law, administration, rhetoric, and occasionally the deployment of soldiers to check violence and dampen the resistance of white citizens and institutions opposed to racial equality. Federal power has not ended the Klan or most related organizations, but it damages their prestige, discourages activists, and demonstrates these organizations' weaknesses.

Majority public opinion has been yet more important. It was not revolution but evolution that made Americans move toward fuller racial equality. Education, religion, and common sense played their parts. The decline of racism was indirectly recognized by William L. Pierce, propagandist, author of The Turner Diaries, and founder of the white racist National Alliance, when he told admirer and terrorist Robert Matthews that "White people are just not in a revolutionary mood now." ${ }^{34}$ Indeed, what is most remarkable about American racists' public demonstrations of the most recent decades is not that they occur, for that is simply an unsavory aspect of a large country with political liberty; it is instead that whenever a racist organization's march permit becomes known, ten times as many citizens turn out on the named day to counter-demonstrate against racism or neo-fascism. This phenomenon has been common all across America. ${ }^{35}$ Racism is publicly despised.

33 This answer reveals the difference between "pro-state" terrorism and right-wing terrorism. The former is exercised by agents or partisans of state power, but in the US case it was precisely federal power that was most active against the racists. Right-wing terrorism of the KKK sort was by substate actors who hated the federal government's intervention in southern American affairs.

34 Report circa 1984 of an earlier conversation, quoted in Morris Dees, Gathering Storm: America's Militia Threat (New York: HarperPerennial, 1996), 146.

35 This also happened in Cologne Germany. In September 2008, a few dozen rightists appeared to rally against "Islamisation and immigration invasion." Forty thousand counterprotestors swamped the scene, and the initial marchers literally fled. See Jess Smee, "ëAnti-Islamisation' Event Abandoned After Protests," The Irish Times, September 20, 2008, available at http://www.irishtimes.com/newspaper/world/2008/0920/1221835126595. html, accessed 6 September 2009. 
A third factor in the "containment" of such terrorism in the United States is the private legal suit. In singular victories that have come in a slow and compelling parade, civil suits are now used by public interest groups-usually in federal courtsto break individual terrorist organizations and hate groups. One leader of this legal offensive is Morris Dees, who in 1981 launched "Klanwatch"-now known as the Intelligence Project — at his Southern Poverty Law Center in Montgomery, Alabama. Three decades of work have provoked several murder plots against the attorney. It was a Dees suit, for example, that ended the reign of terror, hate-speech, and bogus religious rites conducted from a compound of Aryan Nations in Hayden Lake, Idaho. A woman and her daughter passing via automobile stopped near the compound, showed more than necessary interest, and were fired upon from within. In this case of assault, Dees beat the group in court, and Idaho took away Aryan Nations' legal status, money, and land.36 Today the Hayden Lake complex has been leveled and the twenty acres are "Peace Park." With the death of Richard Butler, the group's leader, and the arrest of a purported chief financier, it can be said that the Aryan Nations gang has been broken, peaceably, by domestic legal means. The Southern Poverty Law Center takes credit for similar claims of decisive action against Imperial Klans of America with chapters in eight US states, and the White Aryan Resistance started by Tom Metzger.

Outside the United States, racism, neofascism, and extreme nationalism have many other homelands, and occasionally spawn terrorism. The Czechs, Poles, and Russians have each had unprecedented opportunities for liberal democracy since 1990, but that has not prevented race persecution, beatings, stabbings, and occasionally deaths, especially in Russia. The group Blood \& Honour keeps alive the Nazi flame with members or affiliates in a number of European Union countries and the United States. ${ }^{37}$ Germany had a hundred cases of bodily injury from right-wing attack in the twenty-four-month period 2006-2007, though perhaps no homicide. In Italy, where a center-right government is strongly against illegal immigration, an unforgivable pattern of individual attacks is also visible, causing one local newspaper

36 According to the Southern Poverty Law Center website, "SPLC civil suits would eventually result in judgments against forty-six individuals and nine major white supremacist organizations for their roles in hate crimes. Multimillion-dollar judgments against the United Klans of America and the neo-Nazi Aryan Nations effectively put those organizations out of business. Other suits halted harassment of Vietnamese fishermen in Texas by the Knights of the KKK and paramilitary training by the White Patriot Party in North Carolina." See http://www.splcenter. org/center/history/history.jsp, accessed 6 September 2009.

37 Europol, E.U. Terrorism Situation and Trend Report (The Hague: March, 2007), at www .europol.europa.eu, accessed in 2008. 
headline to declare "a racism emergency." 38 These facts and fears evidence continued dreaming by right-wing supremacists, a dream which for most passed forever in May 1945. Rightist extremism has by no means ended in Europe, although it is much less dangerous than some newer forms of terrorism.

\section{More from the Left: Revolutionaries of the 1960s and Beyond}

Some Italians now fear a revival of their own militant left. This is unlikely, but it does speak to how vividly Italian adults recall the communist and anarchist terror groups of four decades ago. Much of Europe remembers. Those were times of violent upheavals, squatter communes, cocky splinter parties, and anarchism. Such things mixed and flourished in the German north in Frankfurt and West Berlin. French cities including Paris and Toulon saw riots and "Aux Barricades" cries beginning in May 1968. The late 1960s were years of racial and antiwar turmoil in the United States; many around the world were mesmerized by the communist-led turmoil and purges inside China. In the narrower field of pure terrorism, 1968 was above all the year of the Popular Front for the Liberation of Palestine, including founder George Habash and foreign allies such as Hans Joachim Klein and Vladimir Ilich Sanchez ("Carlos the Jackal"). They opened new fronts with international air piracy and lethal attacks in Paris. Many of the European groups networked, holding terrorist summits, meeting under foreign state auspices and in Middle Eastern training camps, buying arms from the same dealers, and occasionally carrying out joint missions, as against North Atlantic Treaty Organization targets.

Most of these later twentieth-century communist organizations failed-for two fundamental reasons. They could not successfully challenge the post-World War II success of capitalism and democracy. The second reason is that, as Lenin and Mao predicted, sporadic violence by small cells was unlikely to enjoy strategic success unless fully integrated with broader political and economic plans. For Lenin, this meant clandestine organization, a vanguard party apparatus, and understanding the perfect time to strike; for Mao, it meant protracted war and competition with the regime on multiple levels until, gradually, the strategic balance of power shifted and the long drive toward state power could conclude. Both men won. But their insight and prescience were not shared by Che Guevara. His school of simple "focoism" that stressed the mobilizational capabilities of small roving armed bands was a failure, after the singular victory in Cuba. Scores of Guevarist-type groups came and went, unsuccessfully and swiftly, especially on the Latin American scene.

38 Rachel Donadio, "Italy's Attacks on Migrants Fuel Debate on Racism," The New York Times, 12 October 2008. 
Two of the continent's most celebrated terrorist groups, in Uruguay and Argentina, respectively, initially enjoyed years of success, until the military intervened and conducted systematic repression with all available assets. That is, powerful terrorists were defeated by greater power. Uruguay's bout with the communist Tupamaros led by Raul Sendic Antonaccio began in 1962, with their first manifesto appearing in 1965. Bank robberies paid for intelligence nets, a huge network of safe houses, weapons, and even underground medical clinics. Armed attacks bedeviled this liberal and admired country, sometimes called the "Switzerland of Latin America." After a few years of revolutionary work, the peace of the capital was in tatters, US personnel came under the gun, and British Ambassador Geoffrey Jackson suffered an infamous and long period in a "people's prison." The group was a founder of modern terrorism in more respects: its partnership with the criminal underworld; ${ }^{39}$ playing Robin Hood distributing cash and food to the poor; large numbers of female members; and the presence in Tupamaro ranks of substantial numbers of professionals and welleducated graduates. ${ }^{40}$ The Uruguayan armed forces intervened in April 1972, later formally taking state power. They soon captured key revolutionary leaders as well as hundreds of cadre, and killed many Tupamaro gunmen. This was decisive; after 1973 the movement was never able to reorganize; after 1976, it had no serious presence at all. The Tupamaros had a successful run for about a decade and disappeared. Uruguay's armed forces defeated them and, years later, withdrew and handed power back over to civilian authorities. A once-flourishing democracy was thus returned to the democratic fold. ${ }^{41}$

Full-blooded state reaction also crushed the Montoneros in Argentina. These terrorists' ideology blended nationalism with Marxist-Leninism and populism, finding a balance of motives that accorded well with political trends in that country. Abroad

39 Some analysts and writers relatively new to terrorism keep reporting the "news" that terror and organized crime have linkages. Perhaps they always have had such linkages, and for the reasons they do now, but certainly the pattern is very old and has often been described. A facilitator of the relationship, globalization, is also not new.

40 An indicator of this legacy of the Tupamaros outside their country is the testimony of Russell Little. This former terrorist admits to the enthusiasm his Symbionese Liberation Army in California had in the early 1970s for the Tupamaros and the movie they inspired State of Siege. Mr. Little mentions most of the factors I touched in the text above while speaking for the Robert Stone documentary film Guerrilla: The Taking of Patty Hearst, (Magnolia Pictures, 2005).

41 When freed from jail in the mid-1980s, Tupamaros leader Raul Sendic refounded his movement as a legitimate political party - the Movement of Popular Participation - and that too is part of how some terror groups end. On such groups as the Tupamaros, the best single source is Michael Radu and Vladimir Tismaneanu, Latin American Revolutionaries: Groups, Goals, Methods (Washington, DC: Pergamon-Brassey's, 1990). 
they opened offices and conducted propaganda; at home they infiltrated Juan Peron's political organizations and conducted bold armed operations, drawing upon as many as five thousand armed guerrillas. These tactical successes stung and bled the authorities, while generating fantastic sums of money, especially via kidnappings of industrialists, including one ransom of $\$ 60$ million; ${ }^{42}$ some money would end up in Cuba, a patron state. But the Montoneros also evidenced vulnerabilities, especially an internal split between leftists and rightists that led even to gun battles. A series of spectacular actions occurred in 1974, but this marked the apex of success for the revolutionaries, as it led directly to a military decision for intervention. The generals took control of all civilian policing efforts in February 1975, and effected a full political coup in March of 1976. The successive months saw multiple and often ugly methods deployed to exterminate this powerful underground. Civilian authorities did not regain power; that would come only with the military despots' blunders and defeat in the Falklands War of 1982.

The Latin world of the late 1960s and the 1970s saw the rise and fall of many other groups, including the National Liberation Action (ALN) organization of Carlos Marighella. He turned from mainstream Brazilian communism into terrorist underground work, and published the 1969 pamphlet Minimanual of the Urban Guerrilla. Then he perished almost immediately in a gun battle with police. His successor lasted only months and the ALN disappeared. The fall of many such short-lived groups makes clear the pattern. Force was met with force, be it legal, covert, or martial. Latin America saw some cases of state appeasement of terrorists, but few instances of successful negotiation leading into satisfactory settlements. Most of the challengers to government were advocates of "absolute war"; they were serious revolutionaries in a hunt for state power, not compromise, and not limited reforms in favor of the poor or the workers. Terrorist parties of this time were creative, exciting to some citizens, and often well led, by charismatic figures or well-educated propagandists, or both, making them strong enemies. As such, Latin states tended to reply slowly but ultimately with great harshness. In Guatemala and Argentina, especially, the government offensive came with free use of torture ${ }^{43}$ and extrajudicial killing. Attrition of the terrorists and victory for the state were normal outcomes. The pattern would remain during

42 The $\$ 60$ million ransom came from the kidnapping of businessmen Juan and Jorge Born in September 1974. See Robert L. Scheina, Latin America's Wars: The Age of the Professional Soldier, 1900-2001 (Dulles, VA: Brassey's, 2003), 299.

43 Of the chronicles of torture in Argentina, one thorough account in English is Paul $\mathrm{H}$. Lewis, Guerrillas and Generals: The "Dirty War" in Argentina (Westport, CT: Praeger, 2002), e.g.,150-159. The book was given to me by a gifted and humane military officer of that country who wished that others avoid his country's mistakes while waging the "global war on terror." 
much of the 1980s and 1990s, as we shall see, but with two notable differences: efforts at negotiation would become more common; and in certain cases, large numbers of Latin undergrounders would fold pacifically into overt political parties, shaping their ambitions in more legitimate fashions. The Colombian M-19 and Salvadoran Farabundo Marti National Liberation Front (FMLN) cadre would do so, following defeats in the fields.

Events in Latin America had strong parallels in Western Europe by 1968 and 1970. Anarchism appeared, after decades of absence in major cities, and to a degree not known in Latin America. Michael “Bommi” Baumann's June 2 Movement in Germany helped reopen wars of youth, radicalism, and criminality against order. His mindless book of those days, Terror or Love?, suggests the lack of strategy in his political circle in Berlin, and thus anticipates the decline and failure of that dimension of the urban and student movement. Joschka Fischer and Daniel Cohn-Bendit did not do notably better in Frankfurt. These self-declared Sponti, or spontaneous ones, unrestricted by Leninist ideas of planning and revolutionary organization, attracted attention and sympathy, and police brutality on occasion, but never persuaded the German people they were all "latent fascists." A concentrated multiyear effort to infiltrate a large factory for Opel cars and bring about workers' rebellion flopped due to immaturity of technique. ${ }^{44}$ Anarchism failed in northern Europe in the 1960s and 1970s, unless a loosening of lifestyles and culture is taken as the only standard of success. Yet Fischer's career is a notable example of one way terror groups end: folding into pacific life. He moved away from the violent underworld and sympathies for armed terrorism, toward the Green Party and elections, and even became the federal republic's foreign minister (1998-2005). Both Fischer and Cohn-Bendit remain regularly in the newspapers, but as personalities and politicos, rather than street fighters.

Europe's communist terrorist groups were more successful, longer-lived, and found more mainstream supporters, than competing anarchist groups. Italy's communists make for remarkable study. Prima Linea, or Front Line, was a large terrorist organization and force of the underground. Trotskyite and Maoist parties abounded, inside and outside the law. Lotta Continua, or Permanent Struggle, boasted some two hundred thousand adherents. The Red Brigades had "columns" in Rome, Florence, Turin, and Milan, even if the last of those turned restless and broke away, taking money and guns with them. Incident levels in Italy rose in the 1970s to shocking heights. There was chaos, perceived and actual, in the country through the early 1980s. Such power in terrorist hands is always to be judged in relation to other political power; in Italy, central government was weak, after decades of tumultuous parliamentary

44 Paul Hockenos, Joschka Fisher and the Making of the Berlin Republic (Oxford: Oxford University Press, 2007). 
politics, enhanced Communist Party strength, and voter disillusionment with such matters as organized crime. Instead of teaching the value of democracy and the mechanisms of rule of law, some social science faculty were poisoning students with contempt of country. A powerful press like the Milan-based Feltrinelli's was no bulwark of the establishment; its heir, Giangiacomo Feltrinelli, was literally a paymaster of various international militant groups, including Italian terrorists. ${ }^{45}$ Hard-working Italian politicians who labored to build working coalitions of disparate parties failed more often than succeeded, and when Christian Democrat Aldo Moro built a bridge to the legal communist left, in 1978, the Red Brigades immediately murdered him for it.

In hindsight, Italian incident levels make it almost incredible that republican democracy survived. That it did, and without even one month of tyranny, is a lesson for all times. No dazzling new computer software or police science was the key. No one leader from the political parties took the helm and showed the way. Security forces were key - but not the only answer. The country's response was a hesitating and uncollective one, but it did succeed. And the most important victory was on the legal front. Instead of sacrificing the law, as in Argentina and Uruguay, legislators studied and improved the laws on terrorism in several key ways. ${ }^{46}$ By measures passed through parliament, police were given greater powers to investigate and to detain suspects. A new group of judges was created to specialize in prosecuting terroristsas also occurred in France. Terrorism ceased to be considered an anomaly or a quirky expression of libertines and became a named offense in state codes. A new provision, however, pointed the terrorist toward a "golden bridge" even as it threatened longer years in jail and encircled his rear with policemen: this allowed any who confessed, and aided police, to dramatically reduce their own sentences. This last point capitalized on the very size of the underground by giving openings to weaker cadre. The terrorist movement contained not just hardened men and women but softer adherents, or comrades grown weary; some of these were willing to talk when captured; pentiti testimony locked up comrades for decades; and the more they gave away, the more the rigor of the terrorist left generally dissolved. The phenomenon illustrated the vulnerabilities of terror groups that seek to become broad insurgencies; counterintel-

45 Claire Sterling, The Terror Network: The Secret War of International Terrorism (New York: Henry Holt \& Co., 1981), Chapter 2.

46 The impressive and deliberative way Italian democracy brought an end to terrorism has been remarkably understudied, despite bales of publications on that country's violence. A recent exception is the well-done Leonard Weinberg chapter "The Red Brigades." It does note that the antiterrorist police DIGOS probably used torture in a very few cases during the attempt to find kidnapped NATO General James Dozier and in its aftermath. Democracy and Counterterrorism: Lessons from the Past, eds. Robert Art and Louise Richardson (Washington, DC: US Institute of Peace Press, 2007); 49-56 are relevant. 
ligence and discipline problems escalate with growth. It was combinations of legal punches and law enforcement-not an end to Communist bloc aid or the dismantlement of the Berlin Wall, that knocked down so many Italian leftist terrorists during the four years 1979 to 1982 . Italy also deployed a specialized police unit, which on 28 January 1982 freed NATO's General James Dozier from a Padua apartment staffed by Brigadists. Incident chronicles then fell nearly silent for the Red Brigades columns; most notations were of arrests of undergrounders, not attacks. ${ }^{47}$

In North America the early 1970s were notable for their violence. This followed the rise in civil rights activism, and included several hideous murders of these activists by right-wingers. Problems were illuminated by arson and rioting in major US cities. The Vietnam War was a second source of domestic violence. It especially affected Americans below the 49th latitude, but the war also inflamed some eyes and ears in Canada.

The Quebec Liberation Front (FLQ) is one of those charted by Dr. Crenshaw's groundbreaking 1991 survey "How Terrorism Declines." 48 She lists the group as active from 1963; one may or may not argue whether her end-date of 1972 is too generous to a group another scholar announces as "dormant" after 1970. The early date marks out this nationalist, separatist, and also leftist revolutionary group as among the first to be active in the Northern Hemisphere. They broke away from a larger leftist group and took aim at military establishments and US economic and political influence in their country. Evading police, one young leader returned to his native Belgium, while Raymond Villeneuve made a pilgrimage to Cuba, helping initiate a long relationship between that island state and North American leftists going underground or seeking to land airplanes they hijacked. The organization survived initial police reaction, found support in anti-Ottawa sentiment in the French-speaking region, published the journal La Cognee (The Axe), and engaged new members such as part-time journalist Pierre Vallieres, who was to write two solid books of propaganda. ${ }^{49}$

47 No Italian leftist killings of the 1980s (after 1981) make the thirty-one-page chronicle of international terror incidents 1920-2007 by Ann E. Robertson, Terrorism and Global Security(New York: Facts on File, 2007). Detailed research by Donnatella della Porta is my main source: "Left Wing Terrorism in Italy," in Terrorism in Context, ed. Martha Crenshaw (University Park, PA: Pennsylvania State University Press, 1995). Certainly there have been leftist terrorist actions in Italy in the last ten years; two murders in 2002 and 2003 were claimed by a group calling itself "Red Brigades," prompting newspaper reports of a revival.

48 Martha Crenshaw is the scholar who has done far more than anyone to understand "How Terrorism Declines." The most significant way my ideas on the topic vary from hers is in judging that government counteraction is very important - often more so than internal factors.

49 I have yet to study Pierre Vallieres' introduction to the movement, Qu'est-ce que le FLQ? But read with profit his 1967/1968 aggressively titled prison memoir White N------ of America: The Precocious Autobiography of a Quebec "Terrorist" (New York: Monthly Review, 1968). 
Robberies and kidnappings built toward a peak that came between the summers of 1968 and 1969; there were a hundred bombings, including that of the Montreal Stock Exchange. These produced vigorous police action by a government long known as quiescent and liberal. In 1970 the FLQ tried to escalate its efforts but overreached with an elaborate plot to seize a British trade commissioner and swap him for prisoners. As this fell into shambles, the FLQ also seized Vice Premier and Labor Minister Pierre Laporte-soon strangled, and dismissed in a terrorist bulletin as "Minister of Unemployment and Assimilation." ${ }^{50}$ Quebec separatism prompted the Canadian government to its own unique form of radicalism: a World War I-era "War Measures Act" was invoked for the first time during peace. This allowed a range of state actions that must have astonished the terrorists and their intellectually loose allies accustomed to chatter about the rightist "extremism" of Ottawa. Sufficiently provoked, Canadian authorities now introduced, against fellow Canadian citizens, such methods as agents provocateurs, systematic intelligence work, countless arrests, and detention without trial. Hundreds of FLQ cadre or sympathizers were entrapped. Within months the cause had been stalled; the country had become silent. Separatism still watered the soil of Quebecoise nationalism, but in legal and fruitful channels, yielding election of the Socialist and former separatist Pierre Trudeau as prime minister in 1968. This victory, by a leader the FLQ's Vallieres had mocked as a slavish compromiser, could just as well be said to show how the democratic path can be an effective path, that forgiving and indisciplined political culture (such as that of Weimar Germany) need not invite the empowerment of thugs (such as Nazis). Quebec separatists won "half a loaf" and it seems difficult to deny that terrorism was one cause of the change. ${ }^{51}$ Now the separatist cause seems satiated; polling gives few indications of support for violence to further set the region apart from Canada. Terrorism ended in a combination of intelligence work, harsh law enforcement, and political accommodation.

Puerto Rico offers a related case, in which serious cultural, linguistic, and political differences may threaten division from a larger multinational country in North America. United States control of the island of the Caribbean dates from the US war with Spain; Puerto Rico was a sort of spoil of war. Advocates of total independence have never been able to capture more than a bare minimum of the island's votes, but their track record of violent provocations is lengthy, reaching back to 1950, when they nearly assassinated President Harry Truman, and 1954, when the group shot up

50 Elanor S. Wainstein, "The Cross and Laporte Kidnappings, Montreal, October 1970," RAND Corporation Report prepared for Department of State and Defense Advanced Research Projects Agency (R-1986/1-DOS/ARPA), February 1977.

51 One contribution to this Canadian case is Ted Robert Gurr, "Terrorism in Democracies," Chapter 6 in Origins of Terrorism, a superb book edited by Walter Reich (Washington, DC: Woodrow Wilson Center Press, 1998). 
the House of Representatives. Arrests ended these cells. The thoughts and resentments that sparked the cases smoldered as embers, however, and produced new flame in 1974 when the Armed Forces of National Liberation (FALN) appeared. They stunned New York City with a tavern bombing of a type Americans associated with Ulster tragedies. Incendiaries were laid in department stores - in a suggestion of later German RAF arson of 1968, or partisans of Iraq who left dynamite in Paris stores in late 2008. Dozens of other attacks followed. Then the action jumped from the eastern United States to Puerto Rico itself, opening a fresh front. But arrests and convictions, as of ten perpetrators in December 1980, squelched the drive. It has been argued that the group ended in 1982; certainly after 1983 there was little to keep the FALN name in lights. Policing succeeded.

But the FALN case reveals the difference between a campaign and a war. One militant Puerto Rican campaign was finished-but not the war. A very similar group had been founded in 1978 and proved well prepared to succeed the faltering FALN. They called themselves the machete-wielders, or Los Macheteros. Displaying that mix of leftism and nationalism so visible in the twentieth-century terrorist world, the new group was an ally of the Marxist-Leninist Puerto Rican Socialist Party (PSP), which itself had connections to Cuba. Their greatest triumphs represented guerrilla war and terrorist robbery capabilities. The first was a 1978 simultaneous incendiary attack on nine US combat planes lined up at a military base near Isla Verde International Airport. The second, five years later, was equally impressive. Having placed a member inside the workings of the Brinks armored car service in Hartford, Connecticut, the group awaited the best day, brought other employees under control, and escaped with $\$ 7.2$ million. Some of it emerged in Robin Hood-style giveaways in Puerto Rican communities; some of it doubtless bought weapons and supplies; much of it appears to have gone to Cuba in a vehicle driven over the US border with Mexico.

The Federal Bureau of Investigation (FBI) took apart Los Macheteros with the same patience and thoroughness it would show later against rightists and "militiamen" in the US "patriot movement" of the 1990s. With surveillance, wire taps, and other efforts (not to mention the special energy of an organization whose office in San Juan had been rocketed by Macheteros), the FBI disassembled this organization, brought its people to trial, and awarded lengthy sentences. Women and men, activists and journalists, social workers, and a Harvard University man were convicted in the late 1980s. The effect on the group was nearly terminal. William Clinton, in a legal but imprudent use of the powers of the presidency, pardoned many of these terrorists as he departed the White House in 2001. Of further concern to counter-terrorists was the continued liberty of Filiberto Ojeda Rios, a long-time Machetero leader. Finally, 
in 2005, the FBI found him, armed, in a house on the island; he died in the subsequent gunfight. ${ }^{52}$

Los Macheteros may be counted among the "deceased" of late twentieth-century terrorist organs. The proximate cause of their expiry was devoted work by law enforcement and successful trials - the latter can never be taken for granted. ${ }^{53}$ It is not irrelevant that the US Navy, after a century of use of Vieques as a bombing and gunnery range, ceased such practices, removing one cause of discontent in Puerto Rico. Perhaps a larger cause of the near-total containment of terrorism by government has been inadequate support for it by other Puerto Ricans. In the same way that a majority of Irish have long rejected IRA methods, the island of four million people, ${ }^{54}$ as a whole, neither votes for nor supports bombings and killings for independence. There is no mass support, above or below the political ground level. On the other hand, Los Macheteros were a success for some years, and before them came other waves in this pool of ethnic and nationalist resentments, which may well be stirred by further storms. Such disturbances can sometimes have a cumulative effect. In tsarist Russia, for example, there were three waves of political terrorism; each of the first two subsided, yet all helped produce the Bolshevik Revolution of October 1917.

As the twentieth century closed, merging with the twenty-first, another nationalist-separatist fighting force with long tenure and a solid level of performance and skill seemed in profound trouble. Basque Homeland and Freedom (ETA) in Spain and France is unlike Los Macheteros because it still has fighters in the field and other operational capacities. But the ETA is at an all-time point of weakness. It survives, but barely; it strikes against Spain, but rarely; it makes headlines, but usually with the capture of ETA shooters or financiers by the more clever security forces of Madrid or Paris. ETA is still standing but may be on its last legs. If so, and ETA ends, it would be significant to world terrorism: The group is now a half-century old, has killed nearly nine hundred Spanish in its operations, and has represented a model, and

52 It is not surprising that Filiberto Ojeda Rios declined to "walk away" from terrorism when discovered in September 2005, or that the FBI had to use their weapons. In a previous arrest, this same terrorist had begun burning documents when agents knocked at his door; he then opened fire with a machine gun, blinding an FBI agent in the eye. Ojeda Rios was disarmed. Later he jumped bail.

53 When a country's justices system is corrupted or incompetent the effects on terrorist groups are doubtless exhilarating, or comic. A different problem are justice systems which are more generous to convicts than to the public on which convicts prey; this allows for short jail terms and releases a man onto the streets who may now be better-trained than ever (by others in jail) for future crime or terrorism.

54 If some four million live on the island of Puerto Rico, more than two million more now live in the rest of the United States - which helps explain the disparate locations of these terrorist attacks. 
been an occasional partner, to other terror groups. Among its greatest successes must be counted the attraction of foreign support-guns from Libya, perhaps advice from Soviet agents, certainly training grounds in Soviet-bloc client state South Yemen in the 1970s - without ever being soiled in its image as an indigenous and independent revolutionary force. This is a difficult balance to strike, but ETA has done it well.

Formed at the end of the 1950s, ETA focused on propaganda and political front activities, initiating systematic violence only years later. Principal Spanish political and security force personnel, and Civil Guards (the gendarmerie) were the most usual victims. Shooting was a preferred method; later would come the car bombs, with their far wider swathes of "collateral damage" to other Spaniards. Assigning a "revolutionary tax" to Basques who were, and were not, engaged in revolution was an innovative and successful financing means the group has never abandoned. But weaknesses were also present. Internecine quarreling over ideology was a plague of the early decades, with some leaders favoring pure nationalism while another strong wing wanted to rally behind declarations of Communism and global revolution. Two other problems were larger, also political. Spain emerged as a strong democracy, as the death of Francisco Franco in 1975 led into the benign monarchy of King Juan Carlos, who transferred some powers over to the National Assembly. Second, in a move largely ignored by terrorism analysts and much of the outside world, the central government bestowed on the Basque lands a high degree of autonomy as to matters of culture, local law, and language. This was quite simply a concession to Basque activism of many types. Initially, ETA reacted violently, probably sensing the subtle dangers (to a terrorist movement) in this prudent concession by Madrid. Over time the government work had its effect, helping to divide the ordinary Basque from his confrere in the terrorist underground.

Today the political fronts that were once so helpful to supporting ETA violence are gravely weakened. Several have been banned by Madrid, including Herri Batasuna (Popular Unity), which in the early 1980s was second in strength in Spanish political parties. Herri Batasuna changed its name to Batasuna, only to again be proscribed. In 2007, 2008, and 2009 the most noted spokesman for the front, Arnaldo Otegi, was under intense police pressure. The larger political challenge is that typical Basques no longer respond to ETA battle cries; indeed, the largest parade on the nationalist issue the country has seen in recent years occurred in January 2007 and it was against ETA terrorism. ${ }^{55} \mathrm{~A}$ final problem is almost overwhelming for the dwindling ranks of ETA terrorists: Franco-Spanish cooperation. This began in small ways in the late 1980s, as France at last began making moves on its side of the border to arrest

55 See “Timeline: ETA Attacks," BBC News, last updated 6 August 2009. Accessed 6 September 2009 at http://news.bbc.co.uk/2/hi/europe/545452.stm 
ETA activists and financiers. For example, a French raid of 1986 on a safe house unveiled much about the group's finances within France, and also captured varieties of international currency. More important was the impetus felt in Madrid to closely collaborate, in 1991 and 1992, to protect impending world tourist events in Spain such as the World Trade Fair, and the Barcelona Olympics of 1992. The late 1990s and early twenty-first century saw continued close cooperation, with arrests on both sides of the Franco-Spanish border. It seemed that new leaders served only months in their roles before capture. The president of France and the prime minister of Spain met in Elysee Palace in January 2008 to advance collaboration on counterterrorism, going so far as to announce creation of a small, combined policing unit. ${ }^{56}$ This now continuous and high-level bilateral cooperation is wrecking ETA. ${ }^{57}$ There is scarcely another case in recent times of two countries combining so well to snuff out terrorist cells - to the immense advantage of both states. ${ }^{58}$

Two other famous and long-standing terrorist entities of our world might have been comparatively studied, until May 2009. Both were Marxist-Leninist; both had enjoyed protracted periods of leadership continuity; both were wealthy; they have been successful as insurgents and leaders of "shadow governments," protecting large swaths of territory, and were thus much more than "bite and flee" attackers of civilian and military targets. Mao Tse Tung's "phase two" warfare, combining guerrilla

56 "Paris and Madrid United Against Terrorism," Le Figaro, 11 Jan. 2008 (trans. CCH).

57 Notices of arrests of ETA leaders have come almost monthly from Madrid or Paris. Presumed leader Javier Lopez Pena was grabbed in France in mid-2008. Then in November came the arrest of "Cherokee," spelled "Txeroki" in Basque, the nom de guerre of Mikel de Garikoitz Aspiazu Rubina, alleged military chief. He and a reported lieutenant, Leire Lopez Zurrutuza are charged with conspiracy and arms offenses, although Txeroki is also suspected of murder - killing two undercover Spanish officers in France in Dec. 2007, reports the Agence France Press; Hurriyet (Istanbul) in English, 22-23 November 2008. See also the story in The Times (London), 18 November 2008. Looking back now, one must remember the early observers of prescience who wrote on the declining power and prospects of ETA. E.g., no researcher's "How Terror Ends" subfile on Basque ETA should be without the Foreign Policy Research Institute article of 8 October 2004, "The End of ETA?" Author Michael Radu has been a reliable and forward-looking analyst of international terror groups for decades. Perhaps taking his lead, the New York Times' Renwick McLean followed on 20 December 2004 with a good dispatch from Madrid: "Bombings in Spain Are Seen as a Sign of Basque Group's Decline, Not Strength.”

58 UK-US cooperation during the R. Reagan /M. Thatcher administrations was an earlier case of excellent bilateral cooperation - against the IRA Provos. 
efforts with semi-conventional and positional warfare,${ }^{59}$ is the best descriptor of the character of these two very important organizations. The FARC of Colombia and the LTTE in Sri Lanka have been feared for their skills in varieties of fighting and terrorism. Now the latter appears finished. About the former, the Colombian government must be especially careful. One of the great yet common sins of counterinsurgency is overestimating successes, of which there were many during 2007 and 2008. But Bogota has more to do, and after FARC there is the smaller entity ELN.

The government and armed forces of Sri Lanka after 2001 were seized with a profound determination that has resonated with their polity and allowed concerted national effort against a powerful in-country enemy. The 1980s and 1990s had seen many ground battles, which together with LTTE terrorism had left over sixty-five thousand dead. A negotiated peace made for a few quiet years, but this was overturned in 2006 and replaced by the most intense fighting. As 2008 finished, regional newspapers were printing accounts of major advances by government ground forces, and the recapture of key towns, as well as the idea that founding leader Velupillai Prabhakaran was living on the run-from jet fighters and ground incursions into his traditional safe havens. In pursuit of him, according to the International Herald Tribune, was Defense Secretary Gotabaya Rajapaksa, a former army officer, a relentless opponent of negotiated concessions or halts in the military offensive, and a skilled coordinator of the air, ground, and naval forces now hunting LTTE night and day. ${ }^{60}$

59 American writers, even in military journals, sometimes misrepresent Mao's concepts. From his writings of the 1920s and 1930s, and the historical work of Samuel Griffith, I see "phase one" warfare as the strategic defensive - characterized by political organization and guerrilla war (as well as terrorism, which Mao usually declines to mention). "Phase two" warfare is a strategic equilibrium in which the insurgency is strong enough to hold its ground, and in which guerrilla war continues, supplemented by positional and even conventional war elements. In "phase three," the insurgency has developed well politically and is battle-tested militarily, and commanders can use all manners of fighting that are appropriate, and especially conventional positional war. Mao's theory is too often treated skeptically, even by scholars; it well accounts for the progress and successful resolution of wars in China (1949) and Vietnam (1975). FARC and LTTE are thus groups that for many years have been locked into "phase two" war with their respective enemies. For an effective use of Mao's theory to illuminate modern Islamist fighting, see Dr. Norman Cigar's introduction to Abd Al-Aziz Al-Muqrin's A Practical Course for Guerrilla War: Al Qaida's Doctrine for Insurgency (Dulles, VA: Potomac Books, 2008).

60 Apart from Sri Lankan progress on the ground, there were many sinkings of LTTE naval assets - that group being a rarity in having such fighting boats and suicide craft. The Hindu (India) reported that the army had the "LTTE Chief on the Run" on 27 December 2008. Press items point to attrition of the LTTE navy in 2008 and 2009; thanks to Larry Cosgriff for the steady stream of clippings. Somini Sengupta wrote the profile on the Sri Lankan minister for the International Herald Tribune, 22-23 November 2008; the paper is now the global edition of the New York Times and one angle of its interest was in Rajapaksa's status as a naturalized US citizen. 
He is the brother of Sri Lanka's president. Now, it may be argued that this leadership duo and fine armed forces have wrecked the guerrillas and terrorists of LTTE. After thirty-five indomitable years, Prabhakaran and many top officers are dead. ${ }^{61}$

\section{Some Groups of Religious Bent}

Terrorism is always political. In the late twentieth century it also became more religious. The 1970s and 1980s offered several extreme versions of Christianity and of Hinduism, which caught up "true believers" in militancy. There were Sikh sects active - and killing — internationally in the mid-1980s. ${ }^{62}$ There was long-running violence from the Jewish Defense League (in the eastern United States, sometimes by individuals with links to Israelis), which may now be spent. But by 1988 and 1990 one could begin to discern newer groups of religious bent-or bent religion. One study has determined that a definite numerical majority of the new groups founded since 1990 avow religious objectives - in front of, or parallel to, political ones. ${ }^{63}$ Most such groups deserve to be taken at their word. Iran's officials supported (then and now) groups of both Sunni and Shia faiths. Beneficiaries include Hamas, which in its wellcrafted charter took an integrated approach to conceptual support for struggle and violence that combined ideas of Sunni Islamism in realms of politics, culture, society, even the arts, and the place of women. There are, newly in evidence, many more religion-inspired political movements in the traditional "arc of crisis" from North Africa through the greater Middle East into Afghanistan and Pakistan.

61 It remains important to learn the fate of certain second-tier leaders, especially "KP" or Kumaram Padmanathan, the logistics chief behind a global and skillful network of money and supplies. Fall of 2009 indicated me may be in custody at last. He has served the Tigers superbly, and almost as long as their supreme leader, and presumably remains in fighting trim. The leader's son, Charles Anthony Prabhakaran, until his death in May 2009, commanded the Tigers' nascent air force. Good short postmortems, summarizing LTTE's effects on the world of terrorism, have been written by Mia Bloom, "What the Tigers Taught Al Qaeda," Washington Post, 24 May 2009, and by Peter Leitner and Rajika Jayatilake, "Lessons from Sri Lanka," Washington Times, 22 June 2009. On the more historical side, the student of LTTE always does well with the detailed books of reporter M. R. Narayan Swamy.

62 One Sikh group took down a Canadian Air flight, killing 329 passengers, in June 1985. Perhaps a scholar interested in how terror groups end, a regional expert such as K.P.S. Gill, will one day detail how it was that international Sikh terror had so short a lifespan.

63 Ami Pedahzur, William Eubank, and Leonard Weinberg, "The War on Terrorism and the Decline of Terrorist Group Formation: A Research Note," Terrorism and Political Violence, Vol. 14 No. 3 (Autumn 2002), 141-147. 
The 1990s also saw the crest of Aum Shinrikyo ("Supreme Truth"), strong in Japan but also Russia. It offered an eccentric mix of worship of Shiva (Hindu goddess of destruction), certain precepts of Buddhism, fashionable mysticism and self-help, and the claims-to-deity of its founder, Shoko Asahara, who, among other innovations, expanded the Buddhist precept of poa into an excuse for mass killing for the "altruistic" purpose of releasing souls for reincarnation in higher forms and better status. ${ }^{64}$

Such perverse ideas and a cult of personality would lead directly to some of the first uses of weapons of mass destruction (WMD) by a substate actor. Asahara had not always obsessed over WMD, but his views darkened dramatically after efforts to openly compete in political elections to Japan's lower Diet in February 1990. The failed exercise brought in fewer than two thousand votes. Humiliation set arrogance and self-interest off together on the road to terrorism, and ultimately mass murder. This devolution is a fair rejoinder to the illogic in the oft-voiced apology for terrorism, that "minorities are driven to violence to be heard." In such cases as Aum, the terror groups are indeed minorities-because their ideas and platforms are simply unpopular; this hardly gives them rights to murder, maim, and menace the innocent until they receive more attention. Asahara hastened his scientific programs, which came to include beam weapons, and Ebola virus, and efforts to acquire uranium. Aum conducted its first WMD attack in April 1990-with botulism. Another dozen WMD attacks of varying type and considerable originality followed, including use of botulinum toxin (against the Imperial Palace) in 1993, a killing with sarin in Matsumoto in June 1994, and a subway attack the next year with briefcases dispensing toxin (botulism, again) through built-in fans. More failed than succeeded, but all prepared the cult well for 20 March 1995 and its mass-casualty success with sarin on Tokyo subways. The world was amazed; Japan was stunned. Maiming many more than it killed, the gas traumatized the Japanese national psyche. ${ }^{65}$

Aum's strengths included fanaticism, peculiarly combined with the high education levels and scientific training of many top cadres. There was as well a fruitful collaboration with Russia. Thousands of members joined in that country, but more importantly, highlevel military and government and scientific circles in Russia sold or gave Aum many valued prizes, from commando training by former KGB experts to a military helicopter to a formula for sarin. ${ }^{66}$ Finally, there was the remarkable budget

64 Of the several English-language books on Aum, the best on this subject may be Ian Reader, Religious Violence in Contemporary Japan: The Case of Aum Shinrikyo (Richmond, Surrey, England: Curzon, 2000), e.g., 193-195.

65 Haruki Murakami, Underground: The Tokyo Gas Attack and the Japanese Psyche (New York: Vintage Books, 2001), trans. A. Birnbaum and P. Gabriel.

66 David E. Kaplan and Andrew Marshall, The Cult at the End of the World: The Terrifying Story of the Aum Doomsday cult, from the Subways of Tokyo to the Nuclear Arsenals of Russia (New York: Crown Publishers, 1996), 108-112. 
of the cult, and its enormous infrastructure, especially in Japan; these were massive, and doubtless helped with political influence and deterred punitive suits. But the most important of Aum's strengths, the one that most prolonged the cult's life before 1995, was Japanese tolerance. A society long known to permit or indulge religious societies and cults, Japan is also a liberal democracy, as hesitant as post war Germany to display a heavy hand in domestic or foreign affairs. This religious, social, and political tolerance was stretched beyond all limits as Aum increasingly preyed upon wider circles of Japanese civilians in the early 1990s. There were kidnappings, druggings, shamelessly inept "medical treatments" in their clinics, disciplinary murders, illegal disposal of corpses, and outright attacks on public figures such as judges who had made anti-Aum rulings in property cases.

The cult's weaknesses, by contrast, were few. For example, Aum required a relative minimum of members, being flamingly elitist in its practices and planning. If public support could not be mustered in elections, it was enough to have the public ignore most of the cult's actions. Even the visions of the apocalypse that darkened Asahara's mind were a source of certain strengths: forcing cohesion; permitting discipline; eliciting tremendously long work hours from members. Only the excess of terrorist killing in the final, successful sarin attack brought the group's end. Once government and police were confronted with the act of 20 March 1995, they snapped to attention and dismantled the decade-old organization. Japan arrested some four hundred members; thousands quit on their own. The guru founder and many top leaders went to prison. Administrative proceedings immediately placed Aum in formal bankruptcy, although their legal charter to exist was not revoked, it seems. One can argue that Aum was decapitated by arrests.

Might Aum be a case of a terrorist group enduring exposure and setbacks by changing its name? This phenomenon, noticed by political scientist Harold W. Rood, accounts for many past actions by sophisticated terror groups-e.g., (1) the way the Palestine Liberation Organization (PLO) created and disused the entity Black September; (2) Irish militants moving from the "Official" Irish Republican Army, to the "Provisionals" (PIRA) in 1969, to "Real IRA" in 1997; or (3) the Kurdish Worker's Party (PKK), which changed its name after its founder's capture in 1999 and then changed it again, to Kongra Gel, and perhaps most recently the Kurdistan Democratic Confederation. ${ }^{67}$ Aum suffered through its public humiliation, mass arrests, and the loss of most of its facilities. It then reemerged as Aleph-the first word of the Hebrew language. On the surface it is different in character: peaceable, though still devoted

67 A 16 April 2009 news item claims that jailed PKK leader Ocalan founded this new front; no date is given. When Kongra Gel was founded, much earlier, other names listed by the US State Dept. for the new entity included the Freedom and Democracy Congress of Kurdistan (KADEK), and the People's Congress of Kurdistan. 
to yoga, rites of self-purification, and other aspects of religion, psychology, and public attention-getting. In a classic exercise of democratic freedom of speech, and an unwitting reminder of how Japan allowed a killer cult such as Aum to develop, an earnest foreign newspaper columnist in Tokyo wrote in apparent anguish over how Aleph's "monks" and "laymen" are piteously "hounded" by police even though "no one can explain what the danger is." Police surveillance is attributed by this newspaperman to the logic that Japan "needs" another threat- that only "a potentially resurgent Aum justifies police budgets and staff levels." 68

Aum changed its name; now observers ask whether it has changed its nature. Some Japanese security officials think Aum's successor does bear close watching: Two years after the sarin attacks, Aum publicity still advertised its interest in poa, and "official guru" duties once held by Asahara were said by adherents to be maintained by his two young children while he is in jail. If thousands of original members did leave the group in 1995, several hundred did not, or later returned, including several top officials who must be considered complicit in the former violence. These include Fumihiro Joyu, who was jailed for three years only to return, gain control of Aleph, and direct it for a half-decade - until a March 2007 schism. None of the capital sentences for murder have been carried out, and many lesser Aum criminals have long since left jail. The new group is also rebuilding physical infrastructure. The shell company that made computers never disbanded in official bankruptcy proceedings by the state, was soon prospering again, with tens of millions of dollars in sales by the late 1990s. In 2002, Kyodo News reported that such sales, and the way Aleph "places the highest level of importance on developing cyber skills" and "identifies itself as a cyber cult," were reasons for US intelligence concern about a cyber-attack by the group. ${ }^{69}$ As of 2005, Aleph owned twenty-six facilities, as well as another 120 residences, according to Japan's national police, and 650 members were living collectively in compounds. Canada, the United States, and the European Union all classify Aleph as a terrorist organization.

Other religious terrorist groups of the late twentieth century have not merely evaded arrest for their crimes; they flourish. This success defies an undercurrent of certain academic writers counseling that "calm observers understand that terrorism always fails." Such a view is nonsense, and both Hezbollah and Hamas offer reproof to the idea. The former was born among Lebanese Shia in 1982; the latter is a Palestinian Sunni counterpart begun some five years later. The trajectory of each helps

68 Richard Lloyd Parry, "Japan Poison Cult 'Hounded" by Police," The Independent (UK), 28 July 2002. Available at http://www.independent.co.uk/news/world/asia/japan-poisoncult-houndedby-police-649680.html, accessed 6 September 2009.

69 Lt. Col. John Kane (USMC) - author of another chapter here - has been of good help in tracking the cyber-side of Aum and of Aleph. 
explain (1) how religion works with politics to produce a successful terrorist organization, and (2) how it is that some terror groups end: in success, for both have now achieved political power by degrees, even if their ultimate objects have not been won. Hezbollah and Hamas have proven they are as sophisticated as they are dangerous.

The so-called Party of God (Hezbollah) began by emphasizing a role as the "Organization of the Oppressed on Earth" - another of Hezbollah's many names. It prudently never abandoned this arm of activity. Human needs are one of the only abundancies of Beirut's Shia slums, and Hezbollah's effective shadow government is at work nourishing, nursing, educating, and propagandizing among those people. Such labors have always helped to make people ignore the rank hubris in calling themselves "The Party of God," on the one hand, and have helped to justify and excuse their terrorism, on the other. Indeed, the infamy of the 1980s days of kidnapping, torturing, and killing hostages including Germans, Frenchmen, and Americans has all but passed out of today's parlance; it has been some time since Hezbollah acted in such ways against westerners. Even after the death of intelligence chief Imad Mughniyah (in Syria in 2008), this remains an organization of capable terrorist operatives-but their emphasis is of other kinds: guerrilla war and politics.

Against any opponent, especially the Israeli Defense Force soldiers, the organization offers a sophisticated and developing array of methods and techniques, from well-disguised road bombs to anti-ship missiles to unmanned aerial vehicles (which may one day be armed). Several thousand men and women are armed by Hezbollah; many more thousands are trained or active supporters; its discipline and ability have been recognizable to military analysts for a decade and a half, and to the world after July 2006, when Hezbollah forces fired rockets into Israeli territory. Hezbollah has another arm, the political. Its skills well suit the freedoms of action offered in a relative vacuum of Lebanese life, where central government is weak and past official pronouncements about Hezbollah's existence and de facto rivalry to the state are permissive or even apologetic. ${ }^{70}$ Finally there is the media arm of Hezbollah, outlets led by Al Manar television. When Israeli bombs destroy the antennas or studios, Al Manar swiftly resurrects - another proof of the way political infrastructure, religious motivation, and state sponsorship may enliven terror organizations under even the

70 While events in 2008 seemed to instruct the national government in the dangers Hezbollah poses inside Lebanon, it has been striking to hear how apologetic have been many previous official statements. Twice I heard radio interviews in which the Lebanese Ambassador to the United States said nothing but good about Hezbollah and blamed the group's violence on the "Israeli occupation" - with the exception of a couple of farms had ended years before. The government spokesmen were ignoring as well the policy ends of Hezbollah, which are contrary to those of democratic multiconfessional Lebanon, and the meddling roles of Iran, which Hezbollah itself counts as its mentor. 
most intense pressure. Like FARC in Colombia, or the New People's Army in the Philippines, the Party of God can seemingly absorb any number of hard hits, year upon year, and carry on, planning for an indefinite future. Conceivably, Hezbollah might one day lead a Lebanese coalition government.

Hamas, the Islamic Resistance Movement, formed amid the clatter of stones and bullets in the first Intifada in late 1987. Like Hezbollah, it enjoys huge subsidies from Iranian coffers ${ }^{71}$ — even while declining to walk the Shiite line in religious affairs. Individuals and groups of Palestinian expatriates worldwide supply other money and aid, as from the United States, Europe, and the Latin "Tri-Border Area." Secular Syria gives fulsome support, and always has, despite profound differences of political ideology. These Palestinian terrorists, politicos, and undergrounders began with the slingshot and the knife-and after all the knife was all that was needed in attacks by "The Assassins" of the twelfth-century Middle East. Swiftly, Hamas graduated to a wide array of weapons, especially the vehicle bomb-yet another "lesson learned" by watching Hezbollah.

While Hamas lacks its Lebanese counterpart's skills in complex guerrilla war, it is possessed of a smooth and practiced political touch. It campaigns and competes well at the polls, and did so well before stunning Fatah (and outside observers) with a January 2006 electoral victory in Gaza. That led in turn to a June 2007 formal political regime in Gaza, which rivaled Fatah's control of the West Bank and also allowed the periodic launching of rockets into Israeli towns. ${ }^{72}$ Hamas, "owning" Gaza, had the power to gather rockets, the ability to launch them, and the responsibility for the war they produced with Israel. The organization also continues its many other forms of attacks on foreigners, especially Israelis, and its bloody rivalry with Fatah Palestinians. More than a few observers of history - or cynics - have said that some terrorists become sanctified once they attain state power. Hamas has some of each-power and legitimacy — and is grappling for more. In its charter, which lays down its views on society, religion, politics, the arts, etc., there is an absolute and oft-repeated proscription against compromise or any mediated solutions to "the Palestinian problem"

71 According to A. N. Pratt, posted to a Middle East diplomatic mission during early 2008, Iran gives Hamas some \$120 million a year. Many others' past estimates of Iranian aid to Hezbollah have been as high.

72 See Country Reports on Terrorism: 2007 (Washington, DC: Government Printing Office, April 2008), and past versions of this State Department annual - which has appeared for three decades. In certain recent years the report suffered from flaws in its statistics, which required correction in some cases. But I do not accept the implications suggested by resultant newspaper articles; I find the report in general an admirable compilation and a sound record of most events, highly useful to scholars, and less flawed than the terrorism coverage of many books and periodicals.' 
that surrender any authority over any part of the land. ${ }^{73}$ Negotiations, not to mention pathways out of violence, are never easy; it is most challenging to make inroads with a religiously motivated terrorist clan. But that is Hamas; its desirability as a partnerto Fatah or foreign parties - in any peace process is only slightly above nil. The end of Hamas is not near. The group is in fact a success.

\section{Graphing Results, in Nine Parts}

The sweep of the twentieth century proffers innumerable examples for the study of how terror groups end. There are hundreds of terrorist groups- too many to master, or even mention, in one essay. And there are different good ways to approach this considerable analytical challenge. We have excluded several notable false starts, such as the odd notion that terror groups have a natural life span. Arguing for the latter ignores the varied and important factors that limit or enable terrorism, ranging all the way from the governmental responses the present author often emphasizes, to the internal and strategic choices the leaders make, and that Martha Crenshaw's scholarship has illuminated.

My distinctive direction, in publications and public lectures of 2004, 2005, 2006, and 2007, was to classify the leading ways that most groups come to their demise: that is, defeat by security forces; defeat by decapitating the leadership; defeat by government's good grand strategy; folding into pacific political life; and terrorist success. The present, more chronologically oriented approach throws different kinds of light. It comes to conclusions about a given group under a pair of analytical rubrics: duration of the group's life, with emphasis on significant actions or years of "main violence"; and extent of successful results. Studied under the first rubric (I) are terror groups whose campaigns are of short duration (five years or less). Groups that ran for a medium length (eight to fifteen years) are rubric II. Rubric III shows protracted terrorist campaigners whose efforts last for two, three, four, and even five decades. With cross-cutting analysis, we identify, first, organizations that expire defeated; second, others that achieved or are achieving limited success and third, groups that have largely succeeded, or appear to enjoy strategic successes now.

73 "The Covenant of the Islamic Resistance Movement," offered up to the "Name of the Most Merciful Allah," is dated 18 August 1988 and may be found on the website of The Avalon Project at Yale Law School, http://avalon.law.yale.edu/subject_menus/mideast.asp 
A chart at the chapter's end graphs these nine sections of results, and a footnote follows here on methodology. ${ }^{74}$

\section{Short-Lived Organizations}

I A: Scores of twentieth-century terrorist groups have had very brief life spans, as little as three to five years. This fact, and the swiftness with which the public forgets them, ought not mean neglect of how they were defeated or brought into decline. Analysts and strategists have often declared that it is best if government can interrupt terrorism or insurgency in its incipient stages. This is usually a regretful post facto complaint about a government's lapse. It can instead be an optimist's observation about how quickly a dangerous terror group has disappeared or been defeated.

Among the first of these, in post-World War II history, was the Secret Army Organization, founded to save European settlers' status and French power in Algeria, but that totally failed within a year and a half — by mid-1962. Certain other European rightist groups were to have life spans of similar brevity, or do only marginally better. In 1980, for example, there was the aforementioned neo-Nazi scare, a natural result of massive bombings in quick succession in Bologna, Munich, and Paris. But the Paris assault was by Palestinians using an invented French cover name, the Federation of National Action. In Germany the "Military Sports Group" of Karl Heinz Hoffman did exist. But it had barely begun to operate when one of its bombs killed thirteen visitors at the Oktoberfest in the Therese Meadow in central Munich; by a year later, the little clan was on the ropes. Peter Janke's admirable dictionary of guerrilla and terrorist organizations devotes a mere eight lines to the Wehrsportgruppe Hoffman. Members went to the Near East for Palestinian training and "were arrested on their return to the Federal Republic ... Hoffman was jailed in 1981, after which the group ceased to exist." 75

74 In this chapter, when speaking of a group's lifespan, I treat its participation in violence of consequence to the state - so some periods of preparation and planning, of several years or even a decade (e.g., Sendero in the 1970s) may be excluded. So too might one exclude years of quiet, after violence (as when members of the Symbionese Liberation Army, having failed, hid underground, 1976-1999). So my chart shows dates for the group's existence, but others for the years of "main violence." Consistent with the PTSS approach, I include discussion of appropriate insurgent groups that systematically employ terror; neither this chapter nor this book is merely focused on small terrorist cells.

75 Janke, 23. The Hoffman group is so lost to history that even the US National Counterterrorism Center's annual desk diaries say nothing of the bombing on 26 September 1980. Yet its significance recurred in 2009 when the famous fall festival in Munich was again directly threatened by terrorists - of al Qaeda. 
American examples of total failure and precipitous decline are too numerous to chart. Illustrative are four groups of the 1970s and 1980s, at different ends of the ideological spectrum: the Symbionese Liberation Army, the United Freedom Front, the Order, and the Army of Aryan Resistance. The first two of these gun gangs were black-dominated leftists who held up banks and shot patrolmen while dreaming of status as a revolutionary vanguard. The other two were white-power groups on the political far right. None of these enjoyed even three good years of real power in their respective undergrounds. A common theme of such cases, in Europe and America, is good and aggressive police work, and resultant attrition through both arrests and gun battles, sapping the vigor of these secular, racist and militant organizations.

Myriad fragments of militant life have burned briefly and expired shortly. Consider Latin America. In Bolivia, the endlessly romanticized Cuba-veteran Che Guevara started a "National Liberation Army" that never exceeded fifty-one troops. It formed in 1966 only to see Che and another leader killed the next year. That drama inspired a successor in Brazil, named the October 8 Revolutionary Movement, which a wave of arrests swiftly reduced to virtual invisibility in 1969. Later, as remnants folded back into Brazil's official communist party ${ }^{76}$ a further Brazilian spore failed to flower, let alone take root: "National Liberating Action" existed from 1968 until $1971 .{ }^{77}$ To consider Europe is to rediscover many such flickers and flights. In Holland alone, now-long-gone entities include the Free South Moluccan Youth Organization (1975-1979), and Red Youth and Red Help groups of the early 1970s. Italy's rightist Revolutionary Action Movement ran for half a decade only, in the mid-1970s. There was the New Force, which lasted six years in Spain, passing from the scene in 1981, and there was Portugal's yet-shorter-lived New Order. Belgium's Communist Combatant Cells surely hold some form of European record for brevity. They operated only from October 1984 to December 1985, whereupon arrest of all four members terminated their tactically effective campaign of two-dozen nonlethal bombings of German, Belgian, and other NATO targets. ${ }^{78}$ Belgium went quiet, as before, and remained so, for many years.

Thus, a range of twentieth-century groups have been stalled or stopped cold in a few years. These include many secular ones, most of those communist. There are also several good right-wing terrorist examples.

76 Radu and Tismaneanu, op. cit., 115-123.

77 Ibid., 115-123; Peter Janke, Guerrilla and Terrorist Organizations: A World Directory and Bibliography (New York: Simon \& Schuster, 1983), 431-440.

78 Yonah Alexander and Dennis Pluchinsky, Europe's Red Terrorists: The Fighting Communist Organizations (London: Frank Cass, 1992), 148-150. Marine Corps University was honored to have both these scholars in our colloquium on "Terrorist Group Vulnerabilities" in Quantico, VA, 30 April 2007. 
I B: The known terror groups of short duration were not all total failures, however; some can claim limited achievements, if only when judged by their own lights, or the praise of their own community or prestigious mainstream partisans. It is reasonable to study the US Black Panthers in this way. ${ }^{79}$ Colombia offers its own case of a militant organization that began with claims of virtue, degenerated into crime and terrorism, and came to an end after a few short years. The United Self-Defense Forces of Colombia (AUC) were an umbrella organization of peasant and middle-class militias that took shape to protect their communities from leftist insurgents. No government help was involved; indeed, AUC existed because of the absence of appropriate governmental effort. ELN and FARC, the Castroite insurgents, flourished for decades in rural Colombia before this challenger arose on the right. AUC leader Carlos Castaño saw explosive growth of his 1997 organization, which protected small farmers, defended some villages and towns, and actively sought out and attacked drug dealers and leftist terrorists. AUC would doubtless claim to have helped check the leftist insurgencies and contributed to their current marked decline. Their success is questionable, and of limited kinds. AUC methods too much mirrored the left's, including its drift into massive narco-trafficking. Before the year 2005, the group's leader had

79 Are the Black Panthers a case of limited success? They emerged in 1966 and 1967 with aspirations to be a sort of armed wing of the civil rights movement. They expected status as a virtuous self defense force, and carried weapons openly amidst claims to protect their communities and their race from the diffidence of a white majority and the aggressions of its white government. Their quotidian work included "survival activities" such as providing food and medical aid and schools in impoverished areas. Their other side was to be found in brutalizing critics, open calls to "Kill the Pigs" (police), and physical attacks on the establishment. The Panthers found themselves very much out-gunned by police; many died at police hands; their supporters often claimed assassination. More (including "Defense Minister" Huey Newton) died committing crimes, or in battles with other black militants. Dozens were arrested and jailed for rape, drug-dealing, assault, etc., illustrating the criminality often typical of a political terror group. A few Panther notables fled abroad, to return years later, usually disillusioned by life in Cuba, or Algeria. Their organized political violence lasted but a half-decade, ending in 1971/1972. Some Panthers spent the next years folding peaceably into American political and social life, winning community and city elections, or devoting themselves to education. Some wrote memoirs. They had not fallen into indiscriminate killing of normal citizens; this set them apart, and helped make them a limited success in America. Panthers would doubtless claim to have helped the civil rights movement by using publicity, psychological shock, and the spectacle of openly bearing arms; they would say they advanced with force while other Black activists advanced related causes in more pacific, less controversial ways. There are many published memoires on these times - some by Panthers themselves - as well as Peter Collier and David Horowitz, Destructive Generation: Second Thoughts about the '60s (New York: Summit Books, 1990), 149 ff; Crenshaw, op. cit., 81. 
disappeared, mysteriously and permanently. And the group was swiftly demobilizing after successful negotiations on amnesty with the government. These talks, generous government terms, and the reassertion of proper powers from the national government of Alvaro Uribe in Bogota and its now-improved security forces add to the reasons AUC has vanished. ${ }^{80}$

Thus, our examination of terror groups yields few that are both short-lived and successful in limited ways. One is a leftist revolutionary and single-race organization in the United States, while the other is a broad "preservationist" terrorist organization that flourished in Colombia.

I C: There are still fewer clear examples of terrorist movements of short duration that came to enjoy total success. Communism did win a violent triumph in Cuba, with remarkable swiftness; but most judge that success came far more from guerrilla war and political work than from terrorism. ${ }^{81}$ If one leaves aside the Cuban case, there may be no short-lived classic terror organizations that succeeded so completely, in so brief a time. So we pass along to our second major rubric.

\section{Midterm Life Spans}

II A: The twentieth century's offerings under rubric two-medium-length terrorist campaigns - are numerous and varied. Some perish in exhaustion, be it physical, psychological, or organizational, and an early post-World War II example was the fatigue of Luis Taruc's Hukbalahaps (or Huks) in the Philippines. Their insurgency and also their flagrant terrorism ${ }^{82}$ ran hard into many obstacles, especially Defense Secretary and later President Ramon Magsaysay. This government wore out its en-

80 US Dept. of State, Country Reports on Terrorism: 2005 (Washington, D.C.: Government Printing Office, 2006), 141-142. The START database offers recent information but does not mention the disappearance of the AUC leader; National Consortium for the Study of Terrorism and Responses to Terrorism, accessed on 12 April 2009 at: www.start.umd.edu/ start/data/tops/ terrorist_organization

81 Dr. David Tucker is one of the very few American authors in recent years to document and discuss Castroite terrorism during the rise to power that ended in 1959 - something older reports and US congressional hearings used to cover. Tucker details several incidents of hostage taking, etc., in a book drawing well on both his Defense Department and academic work: Skirmishes at the Edge of Empire: The United States and International Terrorism (Westport, CT: Praeger Publishers, 1997). My point that guerrilla war was far more important than terrorism is also why this essay does not attempt to include so massive a movement as the Chinese Communist Party's rise to state power in 1949.

82 One notable Huk attack devastated a military hospital and featured widespread murder of patients. That is a tactic even the most nihilistic terrorist groups avoid - although certain Chechens savaged a hospital. 
emy with sophisticated grand strategy. Good political leadership enspirited the new democracy. Fine intelligence work captured a full politburo in Manila. A clever "free land" program seduced away some Huk cadres and demoralized others by answering their calls for "Land for the Landless." Well-trained, disciplined armed forces protected the Filipino people while hunting down terror cells. Eventually the rural leadership, under the labor activist-turned-communist Taruc, capitulated. The campaign ran from 1946 into 1955, a decade. Good leadership and good grand strategy defeated the Huks. ${ }^{83}$

In the Latin world of the 1960s through the 1980s were other forms of terrorism lasting eight to fifteen years until being totally defeated. Many important and compelling revolutionary terrorist organizations were crushed by governmental force. These included the Tupamaros ${ }^{84}$ of Uruguay, who prompted a military coup, and the Montoneros of Argentina, whose cells were ground to pieces by government networks of intelligence, police, and soldiers. El Salvador offers a different kind of case study. FMLN, a front group of some five guerrilla groups, deeply engaged in nationwide terrorism and semi-conventional battles against the military, was finally brought to an end in El Salvador. This did not occur because their demands were satisfied, as one strangely errant new study claims. ${ }^{85}$ It was due to a combination of Salvadoran government and military resistance, enormous financial and intelligence help and military aid from the United States, the decline of Soviet bloc aid, and the close and skillful diplomatic engagement of neighboring and international states in a regional

83 By contrast, Malaysian Communists were pushed out without surrendering. Chin Peng and some remnants held out for decades in Thai border areas, quitting only with a treaty signed 2 December 1989.

84 The Tupamaros became fashionable; their kidnapping and political theater tactics excited widespread admiration on the militant left. One testament to this is Russell Little's words in a documentary film about his group the Symbionese Liberation Army (SLA, of California). He discusses their fascination with the group, the film "State of Siege," and says his own SLA literally took form from a discussion group on political films running in Berkeley; Robert Stone's Guerrilla: The Taking of Patty Hearst (Magnolia Pictures, 2005).

85 "Politics and the FMLN in El Salvador," Chapter 4 in How Terrorist Groups End: Lessons for Countering al Qa'ida by Seth G. Jones and Martin C. Libicki (Santa Monica, CA: RAND, 2008). The notion that this Cuban-organized group of communists and selfproclaimed armed forces was mainly pushing for "reforms" and "for the transition to a democratic political regime" is comically naïve (p. 64). But after its defeats at phase twostyle fighting, and then disarmament under various national and international pressures, FMLN did morph into, a political party and compete in elections, often with a measure of success. A similar error occurs in Table A.1 in which the "goal" of the 2nd of June Movement in Germany is declared to be "policy change." They were anarchists, and later some joined the communist RAF. 
peace process. The latter included the United Nations and states such as the United States, but the most important actors were Mexico and Contadora countries. ${ }^{86}$ This last factor was very important. Like the negotiated conclusion of IRA "Provo" violence in Northern Ireland, it suggests that at the right moment, negotiation may offer its opportunities, even with terrorist enemies.

Western Europeans also grappled with terrorism from the 1960s through the 1980 s, of course. Another dozen campaigns of medium length by self-avowed "urban guerrillas" unfolded in cities and towns, but were doomed to defeat. The far left's fascinating failures included the Turkish People's Liberation Army (1969-1980); Portuguese of Popular Forces 25 April (1980-1986); German anarchists of the 2nd of June Movement (1971-1980); the Baader-Meinhofs in Germany, whose main violence ran from about 1968 to 1977; Front Line, in Italy (1976-1981 ${ }^{87}$ ); and Action Direct in France (1979-1987). The Italian left was torn apart by dissidents and pentiti ("repentants"), who, under prudent new laws, offered testaments against their former colleagues in exchange for light sentences for themselves. ${ }^{88}$ But, in most cases, the European Marxist-Leninist organizations were slowly ground down by civilian law enforcement. TPLA was different; it was among the Turkish clandestine political forces to be forcibly suppressed after a 1980 military coup. The Army took power, defeated many terrorist groups, and gave it back to civilian authorities.

A few of these "rubric II" groups (eight to fifteen years of major violence) have a longer and less-crisp profile: they rose, fell, and yet still defy eradication. Peru's Sendero Luminoso has existed since the earliest 1970s and determined upon armed resistance in 1977, but did not openly attack until 1980. Thirteen years later, the gravest of blows reversed its rise toward national power. In September 1992, a tiny police intelligence unit located leader Abimael Guzman and made an arrest; he has since been locked up on an island under navy control. In practical terms, the Sendero Luminoso campaign ended there. But the insurgency had sunk deep roots, and a scattering of militants never left the field. As a hardened Maoist, Guzman would know the stories of the twentieth-century "comebacks" after jail or hardship: Adolf Hitler, "Long March” leader Mao Tse-Tung, Mahatma Gandhi, Nelsen Mandela, etc. So, while the

86 Interview with Mr. Phil Peters of The Lexington Institute, Arlington, VA, 2006. Peters worked on Central American issues for many years in the office of James A Courter, a New Jersey congressman on the Armed Services Committee, and I also had the honor of employment there.

87 Donatella della Porta, "Left-Wing Terrorism in Italy," Chapter 4 in Terrorism in Context, ed. Martha Crenshaw (University Park, PA: Pennsylvania State University Press, 1995), 121.

88 Sources of interest on this include Richard Drake, The Aldo Moro Murder Case (Cambridge, MA: Harvard University Press, 1995), 259, ff. 
self-described "Fourth Sword of Marxism" kept to his cell during the 1990s, a few remnants stumbled along the shining path of continuous revolution, enlivened by the obvious limitations of Peru's central government, and unchallenged by rivals on the left. In 2007 and then 2008, a few reporters stretched to insist that Sendero is reviving. ${ }^{89}$ More conservatively, we argue that its ideological convictions have allowed it to fail without disappearing. Meanwhile, Shining Path's former leftist nemesis, the Túpac Amaru Revolutionary Movement (MRTA), has totally disappeared. It was weakened in the mid-1990s and decisively crushed by government security forces in 1997.

There are many "studies in defeat" for groups of midterm duration. All imaginable ideological categories are included: leftist, odd combinations of left and right, a religious cult, etc. Some of these groups are mostly urban in their focus, but the range includes many insurgencies as well.

II B: There are also examples of terrorist groups that arose, practiced violence for eight to fifteen years, and ceased operations with a feeling of considerable (but not total) success. Some of these may be found in the Eastern Mediterranean world of anti-British Empire organizations in Cyprus and the Jewish underground.

The National Organization of Cypriot Fighters (EOKA) was an unusual case of a post-World War II nationalist and ethnic Greek group that used terrorism and repudiated Marxism-Leninism. Remarkably independent, it lacked the kind of heavy external support and sanctuary to which some always ascribe insurgent success. The Cypriot Fighters were founded in 1951 by George Grivas; he arrived on the island three years later; April 1955 saw the opening of guerrilla war; the violence when combined with negotiations forced British troops to abandon Cyprus; independence came in 1960. This was, however, but a partial success. Grivas and his sophisticated organization were of the 80 percent on the island whose blood was Greek, not Turkish, and the revolutionaries dreamed of full unity with Greece, not a separate state. And so, a decade later, phase two of the struggle opened under the command of EOKA-B. Now the underground cells attacked indigenous Cypriots, took hostages, and raided armories in a renewed campaign to seize the whole island for unification

89 See, for example, Frank Hyland, "Peru's Sendero Luminoso: From Maoism to Narco Terrorism," amestown Foundation Terrorism Monitor Vol. 6, No. 23 (December 8, 2008). Available online at http://www.jamestown.org/programs/gta/single/?tx_ttnews[tt_ news] $=34237 \&$ tx_ ttnews[backPid]=167\&no_cache=1, accessed 6 September 2009. The article states that "... SL's apparent resurgence may be viewed fairly as an integral part of a burgeoning wave of leftist ideology in Latin America" and "Concern over an SL comeback is well founded." But I think these reports overblown. As a November 2009 briefing at the Marshall Center by a Peruvian Lt.Col. indicates, the actual area of operations of Sendero today is miniscule and very isolated. 
with the mainland. George Grivas died of heart failure in 1974; attrition and jailing took further tolls on his organization. A December 1977 kidnapping of the Cypriot president's son in a plot to free colleagues from prison failed. The group announced dissolution in the next year. ${ }^{90}$ Their legacy is thus mixed: a two-part campaign, separated by a decade of peace, left partial success - the expulsion of the British army and government, but not a new unification with Athens and Greece.

Several of the Jewish organizations fighting inside the British Mandate may also lay claim to a degree of success after mid-length campaigns. The achievement of an entirely new and free democratic state of Israel in 1948 appears in hindsight to some people to justify the actions of Irgun, Lehi, and others. In fact, their terrorism is no more redeemable than that of African National Congress/Spear of the Nation bombers, burners, and assassins whose efforts contributed to destroying apartheid in South Africa. The model for Jewish liberation fighters is no terrorist organization, but instead the Haganah, the mass organization that consistently and successfully resisted Arab, British, and Nazi rulers and deployed guerrilla attacks against their military assets. They were the militant Jews who most succeeded with war. But two further groups - both terrorist—-helped destroy British authority over Palestine. Irgun Zvai Leumi (IZL, or Etzel) was founded by David Raziel in 1937, and was led after his death in 1941 by Menachem Begin. Irgun used terror against the Arab population as well as British targets. The latter included the King David Hotel (1946), which had both civil and military administrative functions; that attack killed ninety-one people and was later detailed in Begin's autobiography The Revolt. ${ }^{91}$ A fanatical group broke away from Irgun in 1940, damning its truce with the British during years of war with the German Reich; Abraham Stern's gang was formally known as Lohame Herut Israel (LHI, or Lehi, or Lechi).$^{92}$ Their attacks on Jewish rivals mirror the inter-ethnic slaughters of a hundred of the twentieth-century's terror groups. The Stern Gang leadership moved to David Yassin in 1942 and the group continued killing: Jews, the British including Lord Moyne, ${ }^{93}$ and, most revealingly, Sweden's Count Bernadotte

90 Janke, 7-10.

91 Menachem Begin, The Revolt:Story of the Ergun, 5th ed. by I.M. Greenburg, trans. Samuel Katz (Jerusalem: Steimatzky Agency Ltd., 1972). Doris Katz, The Lady was a Terrorist: During Israel's War of Liberation (New York: Shiloni Publishers, 1953).

92 Janke, 245-247, and the Jewish Virtual Library, accessed on the web on 20 December 2008.

93 Lord Moyne was a friend of Winston Churchill. After the 1944 murder, the prime minister made a scorching speech in the House of Commons, describing Jewish "terrorism" as evil and risking comparison to acts by Nazi terrorists. This was a principled political posture, the right one - however difficult it must have been for Churchill, well known to be a friend to the Jews since his earliest years in parliament. 
whose very purpose was to negotiate peace in Palestine. Here, too, was a revealing terrorist pattern: the explicit war upon peacemakers. ${ }^{94}$

Several other terrorist groups might claim "limited success" after a campaign of eight to fifteen years' length. A most marginal case is the Armenian Secret Army for the Liberation of Armenia (ASALA), which killed two dozen Turkish officials abroad and left many more bloody spots around Western Europe, hitting hard as late as 1986. Its leader perished two years later. Soon thereafter the "Republic of Armenia" came into being. While this had mostly to do with the disappearance of Soviet power, it dramatically undercut perceived need for terrorism and brought relief to militant nationalists who had earlier waved the flag and the gun. Indeed, at times, violent substate groups are undermined by "political gifts." The sober and considered granting of semiautonomy to Bretons in France, ${ }^{95}$ and Basques in France and Spain, turned many normal supporters against the use of violence against the innocent for larger political ends.

In slightly different light appears the Quebec Liberation Front. Founded in 1963, active by the next year, and soon wholly engaged in violence, they attracted Frenchspeaking nationalists, anarchists, nihilists, and perhaps a few communists; these included several gifted propagandists. The group was never large but it was only shut down with great difficulty by Canadian authorities, as indicated above. Especially due to arrests, FLQ lost all its abilities by 1972. But its terrorists might argue that it had strengthened movement toward provincial self-determination at the expense of rule by Ottawa. Its general political effects reached far wider than its violent acts.

II C: The final parties to tier II are the more successful terrorists, whose eightto fifteen-year campaigns brought them to power. The century's first success was doubtless the Bolsheviks, who achieved the near-impossible between 1905 and 1917, taking total power and immediately using it to terrorize and destroy their innumerable enemies on the left and the right. History's next example might be the more moderate National Liberation Front (FLN) of Algeria. Fatigued with years of squabbling between militants and reformers, the FLN sprang to life in late 1954, published a short powerful declaration to which they adhered closely, and took power in Algiers in 1962. These politicians, diplomats, guerrillas, and terrorists set the revolutionary

94 There have been innumerable terrorist attacks upon those who would ameliorate social and economic problems, and often this is a strategy by the violent. Some of these are a pattern of anti-United Nations terrorism - e.g., today's visible al Qaeda hatreds of the United Nations. I've written on other such attacks in Security Insights, the first of a new series of policy papers from the Marshall Center: "The Assault on Aid Workers: A New Pattern in Terrorism," (January 2008).

95 For example, a Breton Liberation Front fought for independence in northern France from 1966 through 1978. 
standard for the post-World War II era. For example, their clever and violent methods of crushing Algerians opposed to them as "the sole legitimate voice" of nationalism would be aped by Palestinian militants under Yassir Arafat's leadership. They also exported the revolution to the Algerians in France, extracting funding, killing opponents, and undermining French desires to hold the Central Maghreb. The FLN is a brilliant example of how terrorism may end ... in success.

Central America offers the case the Nicaraguan Sandinista National Liberation Front (FSLN). While many neighboring revolutionaries failed, or slipped into dormancy, as in Guatemala, Honduras, or Mexico, the Sandinistas won and won completely. Founded by $1961,{ }^{96}$ at a time when the Cuban and Algerian FLN examples were heated inspirations, the Sandinistas were revolutionary but enjoyed broad popularity among frustrated farmers and other reformers. Soviet bloc provisioning and Cuban direction were of great help in shaping the group. For example, Carlos Fonseca Amador clarified his own allegiances authoring a book, A Nicaraguan in Moscow, that praised Soviet religious and press freedoms. His small organization was at the core of the Sandinistas. Other factions contributed the Ortega brothers, Tomas Borge Martinez, and Lenin Cerna-leaders and security experts who became famous during the war. Arguably their main period of violence is of midterm duration: 1963 to 1979. They slowly discredited the Somoza dictatorship and rattled the regime with terror attacks and strikes on the National Guard. Not long after the United States nervously withdrew support to the sitting government, the Sandinistas marched into Managua (July 1979). Powers of governance lasted eleven years, until they were given away in 1990. The Sandinistas dared to risk elections, and lost. But the turning screw of history kept on, and after years in the wilderness, somewhat less radical Sandinistas returned to power, winning elections in November 2006. Daniel Ortega is president, again.

Asian insurgencies on the Maoist model also demand attention-even when they do not get it from academics in terrorism studies. Let any observer skeptical about "whether terrorism ever works" study the cases of the Khmer Rouge and Communist Party of Nepal (Maoist) insurgencies. The former hacked its way into the capital in 1975 and ruled until expelled in late 1978 by a larger and stronger army-that of communist Vietnam. Comrade Prachanda's Nepalese Maoists also began slowly and with protracted war, by taking over swaths of countryside in the Great Helmsman's way: combining overt politics, clandestine organization, terrorism, and guerrilla war. Then, as Nepal's monarchy tilted in impotence, and reformists began calling out in Katmandu, the Communist Party of Nepal (Maoist), or CPN(M), cut a remarkable political deal that put Prachanda into the prime minister's chair in 2006. His promi-

96 Authorities date the origin of FMLN differently; one sees 1958, 1960, 1961, etc. 
ses to demobilize his thugs have only been partially kept, which means that if overt politicking ceases to meet the Party's needs, other options remain. No one need hurry in a protracted war.

Thus, a midterm lifespan does not signal defeat, necessarily. Religio-nationalist groups in this category have flourished and survived for many years and eked out gains of demonstrable kinds. Several secular leftist and revolutionary organizations using terrorism have similarly enjoyed limited success. Their will to survive, and their gains over time, indicate the truth in an old maxim about guerrilla war: that in some ways, merely to carry on fighting is to succeed.

\section{Groups with Longevity}

III A: The third and final tier is of organizations with great longevity-protracted campaigns by terrorist groups. Some were ultimately and thoroughly beaten. The international anarchists, dramatic actors of the last two decades of the nineteenth century, after 1920 all but ceased affecting the political world. Later came an ideological opposite but similar fate: the unbelievably long and entirely useless effort of Chin Peng and others of the Malayan Races Liberation Army to create a communist state ended formally with his surrender in 1989.

One might reasonably take the long view of a "war"-rather than study a given group's shorter "campaign"- - when examining nationalist militants in Ireland, or in Puerto Rico. Puerto Rican nationalist attacks in the early 1950s, the latter 1970s, and the early 1980s all melted away as tactical successes had no real strategic results. Successively, the Puerto Rican Nationalist Party, the Armed Forces of National Liberation (FALN), and then Los Macheteros have won no important political change. The Commonwealth remains a commonwealth; polling data still show revolution or total independence to be a far-fetched idea; new recruiting is minuscule; no foreign powers have stepped in to aid the militants other than Cuba-now largely inactive in this respect.

The Tamil Tigers of LTTE lack roots so long, but they did begin as early as $1972 .{ }^{97}$ They survived innumerable government campaigns and were only smashed in their "liberated zones" in early 2009. Anther communist group of very different and urban character enjoyed almost as long a lifespan, but was decidedly less lethal. Revolutionary Organization 17 November was made up of a handful of Greek Marxist-Leninists who operated in Athens for a quarter century. They attacked Greeks, Americans, and

97 A more common date of origin for the Tigers is 1976. This author chooses to begin when Velupillai Prabhakaran founded the Tamil New Tigers, 1972. An active terrorist and guerrilla in the next years, he refounded the Tigers as LTTE in 1976. 
NATO personnel, sometimes using the same Colt pistol, and also targeted multinational corporations. They managed to do so year after year, never even suffering a single arrest. But the small size that made this evasion possible ${ }^{98}$ also flagged N17's unpopularity and failure to recruit. Lack of numbers likewise determined that if all operations might be secure from police, there would only be very few operations. As the 2004 Athens Olympics approached, Greeks in government took a new attitude toward terrorists. A break for security forces came when a 17 November man failed in a bombing, wounded himself, and then talked. Immediately most of the small organization was arrested, and trials led to long sentences. The new group "Revolutionary Struggle" now seeks to revive leftist terrorism in Greece, but 17 November has come and gone. ${ }^{99}$

Thus, there are certain examples of fighting groups that devoted decades to their will to power and yet entirely failed. Those studied here are mostly "internationalists" of one sort or another, including anarchists and leftists. Two communist insurgent groups also manifest strong quotients of nationalism in their work. And, if one examined state terrorism sponsors, Libya's three-decade record would fit here-as a failure. ${ }^{100}$ However, it is more common for a well-organized fighting group to achieve more over time, to create "liberated zones" or otherwise make permanent effects, which brings us to the next rubric.

98 So long did N17 prosper that some began to whisper that the socialist governments of Greece did not care to arrest the terrorists, given the targets they were choosing. Mr. Keith Weston, once part of an official British contingent in Greece, disagrees. He believes the extremely small size of the group, and the blood connections many had as well, ensured secrecy.

99 The Kurdish PKK, the most beguiling of cases, may or may not deserve a place here in section. III A. Once easily classified, this protracted insurgency has become an analytical challenge. Founded by Abdullah Ocalan in the mid-1970s, and ruled continuously by this charismatic leader, it was decapitated in February 1999 with his arrest and rendition. Kurdish violence all but disappeared for some four years. Ocalan's announcements from jail appeared to dissuade loyalists from terrorism, and no clear successor has appeared. The PKK appeared defeated. Then a shadow came over Turkey's accomplishment: violence by Kurdish militants of unclear loyalty slowly reappeared. The leader's son is an active militant, and new organizations that may or may not be well linked to the old have appeared and are fighting - in Turkey and from Iraq. There is, for example, the "Kurdish Freedom Falcons," which the US State Department initially reported on neutrally, and years later began referring to as a militant wing of the PKK. Today one must speak of a phoenix of Kurdish militancy. The US State Department, and the government of Turkey, see a new chapter in a long PKK life. Either of these different views may be defensible; a historian might well prefer the latter.

100 Ken Duncan, the PTSS program's expert on Middle Eastern states that sponsor terrorism, adds that Syria has been successful in its use - a contrast with Libya. 
III B: Terrorist groups of protracted duration that did or have achieved limited gains are many and richly varied.

If we chose to study the Provisional Irish Republic Army as a discrete entity, a guerrilla and terrorist organization with an intimate party affiliate, it began in a 1969 split with other Nationalists and ended its violence against unsuspecting civilians with the 1998 Good Friday Accord. That Irish Republican Army, so delimited, is a clear case of limited success. Militancy had of course cropped up often before the twentieth century, as when Napoleonic France aided Wolf Tone, and a few decades later when American citizens began contributing weapons and money to other insurrectionists in Ireland. ${ }^{101}$ A periodically successful Irish fight began in 1916 and ran right through the twentieth century, manifesting guerrilla and/or terrorist variants. The IRA had some sleepy years in the twentieth century but came to life as the "Provos" in 1969 and 1970, fired with passion over civil rights, as well as nationalism, and a dash of Marxist-Leninism. A few British overreactions, and indeed the 1972 "Bloody Sunday" event, encouraged the hard men and drew in recruits. By the 1990s, many felt a kind of stasis; the Provos could neither win nor be beaten. Their leaders bent more to politics and sought to do less with terrorism. They negotiated with London, won limited concessions, and joined governance circles in the Stormont-based parliament in Ulster. There is no unification of Northern Ireland with the Eire republic, and the IRA Provos submitted to disarmament - or partially so. But on the other hand the Provos have seen comrades released from jails by the score; they operate openly, peaceably, and respectably; they have not surrendered their many foreign friends. And they can return to terrorism if they so decide. This could occur as a group effort, in theory, or, more likely, scattered individuals may choose to join extant splinter groups such as the Real IRA.

The irony in this is that Orangemen, too, can claim partial success from terrorist campaigns. And perhaps they should. Ulster Volunteer Force (which declared war on IRA in 1966) and Ulster Freedom Fighters (begun 1973) are as able as the PIRA/ Provos' Gerry Adams and Martin McGuinness to see a "partial victory" in the status quo of the last decade. They fought below and above ground for decades, hurting as many Irish as English, but always securing prestige and precious political space in that tormented island. Unlike smaller killing squads (e.g., Red Hand Defenders), the UVF and UFF also work with political fronts, making them more significant as well as more morally credible. Now these major Loyalist groups have put down guns and taken up balloting; all their supporters, in English and Irish politics, may see the old terrorists sharing banal administrative duties and profound political responsibilities

101 Jack Holland, The American Connection: US Guns, Money, and Influence in Northern Ireland (New York: Viking, 1987). 
in a new parliamentary structure in the Stormont parliamentary building just outside Belfast. The Orangemen of illegal bands are "preservationist" ${ }^{102}$ terrorists who have arguably helped keep the six counties under the British Crown; at least, few would dare tell them otherwise.

Twentieth-century history is crowded with candidates for this rubric of "protracted campaigns leading to limited success." American labor militants-a few of whom were terrorists-gradually won major concessions, first in wages and then organizational rights and later in benefits, and came to struggle pacifically and successfully in recent decades. The traditionalist and racist American Ku Klux Klans have atrophied drastically; once a mass movement, now but numerous cells, they have never disappeared in a hundred and fifty years of influence. In Colombia, FARC and ELN are examples of rural insurgencies, widely using terror, that seem uneradicable and have endured for half a century. That mark may one day be met by India's Naxalites-Maoists who are in effect a shadow government in certain areas. Western Europe's ETA Basques have lasted exactly a half-century. France remains bedeviled by the Corsican National Liberation Front, which still lights up strings of bombs to keep alive hopes of withdrawal from metropolitan France and its system of district governance-as Algeria succeeded in doing in the insurgency ending in 1962. France is also troubled by being the Euro-home to the secular and ideologically vague People's Mujahideen of Iran (PMOI), also known as the People's Mujahideen al Khalq (MEK), which is still under veteran leaders' wings. Contained and disarmed on Iraqi territory and subject to US and Iraqi controls up through 2008, MEK still flourishes politically abroad. While this is especially true in France, MEK also enjoys friends in the halls of US and European national parliaments.

Certain Middle Eastern groups are marginal but unrepressed; these include the Popular Front for the Liberation of Palestine-General Command, a Syrian-supported terror outfit that has operated for decades with no one to control it but Israeli forces. Hezbollah has turned covert and overt organization and violence ${ }^{103}$ into de facto political control over large swaths of Lebanon. Their success in national politics in Lebanon has been immense, as indicated by presence in political bodies and the na-

102 This unique term "preservationist" is from Bard O'Neill. The term "pro-state" terrorist is inferior because it is less exact; some right-wing groups want to preserve the cultural or political status quo, not necessarily the sitting government, with whose police they often quarrel.

103 Stephen Morris, an Australian scholar and former colleague at the Naval War College, propounded a very useful scheme for beginning study of an insurgent group - analyzing its performance in the overt political, the covert political, and the military realms. If we group terrorist violence in with the third category, the approach has much value for study of organizations such as Hezbollah and Hamas, and to lesser degrees al Qaeda. 
tional political life. The "mainstreaming" of such terrorists is a reproof to thinking that terrorism "has always failed and . . . will fail again," as one post-9/11 argument proclaimed. Much more narrowly, a think-tank report of 2008 about the fate of terrorists concludes that "Religious groups rarely achieve their objectives." 104 But even that more careful view is misleading - given the impressive if incomplete successes of such religious groups as Hezbollah and Hamas.

Thus, analysts may find innumerable cases in the range of moderately successful groups engaged in protracted struggle and terrorism. From the radical rightist and "preservationist terror groups one may look to the left, and nationalist-leftist, and onward to religiously motivated politicos. The most successful have strategies that far exceed terrorist methods - combining these in a prudent and broad approach to power. Some may ultimately fail, but others appear likely to move to greater plateaus of success.

III C: Earlier pages and rubrics explored terrorist successes-e.g., Bolsheviks, the Algerian FLN, Greek-Cypriot EOKA, some Jewish groups, and Sandinistas-that achieved some or all of their strategic objectives after violent campaigns of medium duration. But there are as well a few groups of longer life that did come to triumph and take state power.

In South Africa, 1961 saw the creation of "The Spear of the Nation," forged to do bloody work for the African National Congress (ANC, founded 1912); this midcentury strategic choice followed years of indifferent political success; now ANC militants bombed energy companies, shopping centers, and other civilian targets. Later they commenced "necklacings": victims were bound, seated, and then burned, by means of placing an automobile tire around the torso, filling it with gasoline, and torching it off. This was apparently done to murder black rivals or dissidents more often than to white South Africans, an example of an old pattern-terrorism for discipline and control of “one's own." In retrospect, ANC terrorism led toward stunning electoral triumphs - not unlike the ways Palestinian terrorism has done so.

Yassir Arafat's Palestine Liberation Organization (PLO) was created in 1964. Like most revolutionaries, it aspired to match the fresh triumph of the FLN in Algeria. Fatah was the armed force the PLO created and shaped. After it came innumerable subgroups and splinters, which achieved a certain advantage in deniability and decep-

104 The second source, described as more careful, is the aforementioned Jones/Libicki study dated 2008, which declares on p. xiv: "No religious group that has ended achieved victory since 1968." That student of history inclined to think terrorism fails will be most content with the views of, and best instructed, in studying the works of Walter Laqueur. His decades of fine work, based on many primary sources and varied languages, has set high standards for writing the history of terrorism. 
tion. But, except for Abu Nidal's gang, ${ }^{105}$ which left the PLO only to hunt its former colleagues, the PLO splinter groups were generally helpful and useful to Arafat. He might support an Abu Abbas (of the Palestine Liberation Front) in one season, then hold him at arm's length later, and welcome him back in a new springtime. Skillful as an organizer, adequate as an orator, immovable as the controller of PLO businesses and income streams, Arafat won. It took three decades of his own blend of protracted war, yet he created a Palestine homeland. It may today be divided in civil war. But it is a statelet; Israel has departed and hopes to avoid unpleasant returns; foreign governments jostle one another to lead in supplying humanitarian aid to Palestinians under the control of the Palestine Authority; Hamas terrorist acts all rebound in favor of PA legitimacy and give the older more secular guard airs of empathy. Our Marshall Center is among the many mainstream locales where Palestine authority security officials are now schooled in countering terrorism.

Thus, PLO and Fatah and the ANC's Spear of the Nation are among the few cases in which long-term efforts including systematic terrorism have led eventually to strategic success.

\section{An Afterword: Whither al Qaeda?}

Al Qaeda falls within our rubric of real longevity and limited success (III B). This innovative, international, and powerful organization has taken body-blows without going down. It lost in Afghanistan and still found cover. It absorbed members of Egypt's battered al Jihad group at the end of the 1990s; in early 2007 it absorbed North Africans of the Salafist Group for Preaching and Combat; European converts and others have joined to offset losses. Many senior and mid level leaders have been killed or captured, yet several of the newest leaders are from the ranks stupidly released from Guantanamo and other prisons. ${ }^{106}$

Certainly al Qaeda and its allies will never achieve their New Caliphate. But what matters is that they are fighting for it. No one should claim they have "failed" when top leaders with long experience and obvious charisma remain in the field (Osama

105 The Abu Nidal Organization flourished for a quarter-century and killed some nine hundred people before expiring from combined causes. These culminated in the shooting of the leader in Iraq but included internecine violence in ANO, repudiation by other Palestinians, and a clever US effort in counterterrorism thus far described by almost no one in print; see the chapter on "History" in David Tucker, op. cit.

106 ABC Radio News, 24 January 2009 named a released terrorist who rejoined al Qaeda. These incidents have occurred perhaps once a year, during the very same years of popular European and American agitation for closure of the detention facility at Guantanamo Bay (on US-controlled land in Cuba). 
bin Laden, Ayman Al Zawahiri, and Taliban partner Mullah Omar). Al Qaeda's terrorism has made impressions on the politics, public opinion, or defense policies of a hundred countries worldwide, as in influencing the US troop withdrawal from Saudi Arabia, bin Laden's birthplace. It accomplishes such things; holds up its intellectual, moral, political, and religious banners of attack; and protects many of its human and financial assets in the face of the largest manhunt in global history. To call al Qaeda a "failure" would be the most desperate form of false hopes. It is apparent that states, and the international community, have much to do before al Qaeda ends.

Dr. Christopher C. Harmon Dr. Harmon has long-held interests in the two subjects of this text: strategy and terrorism. His first book, coedited with low intensity conflict expert David Tucker, was Statecraft and Power (University Press of America, 1994), a work in honor of a teacher of strategy, Harold W. Rood. Harmon taught on the Strategy \& Policy faculty of the Naval War College, Newport, RI, and then wrote and directed a strategy syllabus for 200 Marine majors, foreign allies, and US civilians at Command \& Staff College, Quantico Virginia, where he later held Marine Corps University's Kim T. Adamson Chair of Insurgency and Terrorism (2005-2007). He is the author of two editions of the graduatelevel textbook Terrorism Today_published by Frank Cass (2000) and Routledge (2007), as well as chapters on terrorism and counterterrorism for Fanaticism and Conflict in the Modern Age (2005) and The American Military Tradition (2007). Two of Dr. Harmon's articles have appeared in the journal Vital Speeches. The US State Department gave him a Distinguished Public Service Award. From March 2008 through September 2009, Dr. Harmon was executive director as well as curricula chief of the Marshall Center's Program on Terrorism \& Security Studies; he is now Director of Studies. 


\section{Recommended Readings}

Alterman, John B., Martha Crenshaw, Teresita Schaffer, and Paul Wilkinson. "How Terrorism Ends." United States Institute of Peace Special Report, 25 May 1999. http://www.usip.org/files/resources/sr990525.pdf

Crenshaw, Martha. "How Terrorism Declines." Terrorism and Political Violence, Vol. 3, No. 1 (Spring 1991), 69-87.

Crenshaw, Martha. "Why Violence Is Rejected or Renounced: A Case Study of Oppositional Terrorism." Ch. 9 in A Natural History of Peace, ed. Thomas Gregor (Nashville, TN: Vanderbilt University Press, 1996), 249-272.

Harmon, Christopher C. "How Al Qaeda May End." Lecture (host: James Phillips) \& Backgrounder 1760, The Heritage Foundation (19 May 2004), 1-13. www.heritage. org/Research/HomelandSecurity/bg1760.cfm

Harmon, Christopher C. "How Terror Groups End," web-cast lecture from The Woodrow Wilson Center, 20 March 2006. Hosts: Dr. Robert Litwak \& Dr. Bruce Hoffman. Summary and event film: www.wilsoncenter.org/index.cfm?fuseaction=events. event_summary\&event_id=1770...

Jensen, Richard Bach. "The International Campaign Against Anarchist Terrorism, 1880-1930s." Terrorism and Political Violence, Vol. 21, Issue 1 (January 2009), 89-109.

Kassimeris, George. "Last Act in a Violent Drama? The Trial of Greece's Revolutionary Organization 17 November," Terrorism and Political Violence, Vol. 18, No. 1 (March 2006), 137-157.

Ross, Jeffrey Ian, and Ted Robert Gurr. "Why Terrorism Subsides." Comparative Politics, Vol. 21, No. 4 (July 1989), 405-426.

US Dept. of State, "Rescission of Libya's Designation as a State Sponsor of Terrorism," "Significant Events in US Libyan Rapprochement," and other press releases of 15 May 2006. Available at http://libya.usembassy.gov 


\section{Bibliography}

Alterman, Jonh, Teresita Schaffer, Paul Wilkinson, and Martha Crenshaw. How Terrorism Ends. United States Institute of Peace Special Report, 1999.

Crenshaw, Martha. "How Terrorism Declines." Terrorism and Political Violence 3, no. 1 (1991): 69-87.

Crenshaw, Martha. "How Terrorism Declines." Terrorism and Political Violence 3, no. 1 (1991): 69-87.

Donadio, Rachel. Italy's Attacks on Migrants Fuel Debate on Racism. The New York Times, , 2008.

German, Mike. Thinking Like a Terrorist: Insights of a Former FBI Undercover Agent . Washington, DC: Potomac Books, 2007.

Henissart, Paul. Wolves in the City: The Death of French Algeria. London: Rupert Hart Davis, 1971.

Holland, Jack. The American Connection: US Guns, Money, and Influence in Northern Ireland . New York: Viking, 1987.

Jensen, Richard Bach. "The International Campaign Against Anarchist Terrorism, 1880-1930s." Terrorism and Political Violence 21, no. 1 (2009): 89-109.

Laqueur, Walter. The Age of Terrorism. Boston: Little, Brown \& Co, 1987.

McCann, Joseph T.. Terrorism on American Soil: A Concise History of Plots and Perpetrators from the Famous to the Forgotten . Boulder, CO: Sentient Publications, 2006.

Pedahzur, Ami, William Eubank, and Leonard Weinberg. "The War on Terrorism and the Decline of Terrorist Group Formation: A Research Note." Terrorism and Political Violence 14, no. 3 (2002): 141-147.

Sterling, Claire. The Terror Network: The Secret War of International Terrorism . New York: Henry Holt \& Co , 1981.

Thorup, Mikkel. "The Anarchist and the Partisan: Two Types of Terror in the History of Irregular Warfare." Terrorism and Political Violence 20, no. 3 (2008).

Tuchman, Barbara. The Proud Tower: A Portrait of the World Before the War, 1890 1914 . New York: Scribner/Macmillan, 1966. 